\title{
How Pervasive is the Effect of Culture on Stock Market Linkages? Evidence across Regions and Economic Cycles
}

\author{
Vikkram Singh \\ Ph.D. Candidate Griffith University \\ Professor \\ Sheridan College \\ Email: vikkram.singh@griffithuni.edu.au \\ Dr. Bin Li \\ Senior Lecturer \\ Griffith Business School \\ Griffith University \\ Dr. Eduardo Roca \\ Professor \\ Griffith Business School \\ Griffith University
}

Keywords: stock market linkages, culture, religion, language, liquidity, time-variant, quantile regression.

JEL Classification: F36, G15

Corresponding author: Vikkram Singh, Department of Accounting, Finance and Economics, Griffith Business School, Griffith University, Queensland 4111, Australia; Email:

vikkram.singh@griffithuni.edu.au; Tel: +1-647-273-2892.

Page 1 of 43 


\section{How Pervasive is the Effect of Culture on Stock Market Linkages? Evidence across Regions and Economic Cycles}

\section{ABSTRACT}

We conduct a comprehensive study on the effect of culture on stock market linkages. With data on 25 national stock markets, a quantile regression model is used to estimate the determinants of market linkages using culture variables such as language, religion, and Hofstede's culture dimensions while controlling for distance, economic and legal variables. Further, we test whether these effects hold across regions and if changes are detected during periods of market crisis. We also test if market liquidity, an indicator of market efficiency, diminishes the impact of culture on market linkages. The main conclusion is that culture preferences shape investor choices, which affects integration between stock markets. The equity markets with similar cultural traits tend to increase market linkages; however, we observe differences across regions. Furthermore, liquidity and economic uncertainty fail to have an impact on the significance of culture variables as determinants of market linkages. 


\section{Introduction}

Attempts to explain stock market linkages in the finance literature have focused on estimating the determinants of these linkages ${ }^{1}$. However, most of the studies limit themselves to economic determinants and do not take into account behavioural variables such as culture, language, and religion (Stahl and Voigt, 2003; Stafford and Miles, 2013). A key area of literature gap is the role played by culture in the development of market linkages. The need to study the impact of culture on market linkages is warranted since several studies document the role of behavioural traits such as culture in the development of financial markets (De Jong and Semenov, 2002; Pirouz and Graham, 2010; Dutta and Mukherjee, 2011). Also, the available research in this area of finance is not only scarce, but the findings of the studies are inconclusive. Whereas some studies find culture to be a significant determinant of market linkages, several fails to use a comprehensive measure of culture dimension - for example, King et al. (1994) use investor sentiment while Wälti (2005) uses common language as a proxy for culture. Not only does the available literature lacks consistency in the definition of culture, but the existing studies also provide conflicting results. While some studies identify culture traits as a significant determinant of market linkages (King et al., 1994; Stulz and Williamson, 2003; Lucey and Zhang, 2009), others point to no significant convergence pattern in regional markets in Asia (Danareksa Research Institute, 2004; Kim et al., 2006) and Europe (Gallagher, 1995; Knif and Pynnonen, 1999) despite these markets sharing common culture traits.

Culture dimensions are expected to exert a strong influence on market linkages as investors' choices of investments are likely to be influenced by preferences for markets based on the similarity of behavioural traits. This hypothesis is based on the argument that individuals in similar cultural settings are likely to display conformity in their behaviour and decisionmaking process. Given that the equity prices are determined by collective buying and selling decisions of investors, if investors across markets share common culture traits, then their investment choices are likely to increase linkages between such markets. The increase in market linkages due to the increase in capital mobility and lower transaction costs can improve market efficiency. However, an increase in ties due to behavioural factors such as culture can

\footnotetext{
${ }^{1}$ For a short list, see Cavaglia et al. (2001), Forbes (2002), Pretorius (2002), Hardouvelis et al. (2006), Bartram and Wang (2011).
} 
lead to the phenomenon of herding during a market crisis and distort market mechanisms. ${ }^{2}$ Thus, investigating the role of behavioural determinants such as culture can also shed light on the state of market efficiency.

In this paper, we contribute to the literature on market linkages by testing the hypothesis that culture influences linkages between financial markets. A baseline quantile regression model is used to estimate the impact of culture variables on stock market correlations along with several other variables. Quantile regression methodology is ideally suited for our data with non-normal distribution and allows us to observe the changes in the determinants over the various quantiles. The culture variables used are language, religion and Hofstede's culture dimensions, ${ }^{3}$ which include power distance, individualism, masculinity, uncertainty avoidance, orientation, and indulgence. Control variables are also used such as geographic distance, trade linkages, legal orientation, legal enforcement of contracts and differences in the GDP growth rate. In general, the results show that culture variables are significant determinants of market correlations - an increase in the culture distance decreases the linkages between markets, whereas the markets with similar language and religious beliefs are more likely to report higher linkages. We also classify the markets into three geographical regions to test the hypothesis that the significance of culture as a determinant of market linkages is consistent across geographic regions. Results indicate that culture variables have a bigger impact on market linkages in the Asia-Pacific compared to Europe and the Americas. Further, we test the hypothesis that the significance of culture diminishes in markets with high liquidity. Our results reject this hypothesis as culture distance, language and religion are found to be significant determinants of market linkages in active markets. We also investigate whether the effect of culture varies between times of calm and turbulence. To do so, we test the hypothesis that the significance of culture declines during periods of global market crisis due to the prevailing negative sentiments across markets irrespective of culture traits. We reject this hypothesis, as the culture variables remain significant determinants of market linkages during times of market crisis.

Our paper contributes to the existing literature on market linkages in several ways. First, we use a comprehensive model incorporating both economic and non-economic variables to evaluate the impact of culture on market linkages. The bulk of academic research in finance has, for the most part, avoided behavioural factors in the explanation of market linkages. Second,

\footnotetext{
${ }^{2}$ The herding behavior refers to the investors mimicking the actions of a larger group which could be irrational and can lead to market crashes (Boortz and Jurkatis, 2013).

${ }^{3}$ The Hofstede's culture dimensions are used to formulate the culture distance variable, as described in Section 3. 
our paper uses a comprehensive data representing markets across the world and thus overcomes the shortcomings of some of the literature in this area, which tends to be region-specific. Third, by segmenting the data according to the periods of turbulence and calm, we can isolate the effects of market turbulence on the significance of determinants, another area of research ignored in the literature. Lastly, our paper investigates if liquidity impacts the role played by culture on market linkages. Given that high liquidity characterizes active markets, a sign of market efficiency, we can test if behavioural traits such as culture matter in such markets.

Our study not only contributes to the literature on financial market linkages but can also assist portfolio managers and policy decision makers. A better understanding of the market linkages can help portfolio managers in gaining risk-adjusted returns by being able to diversify across regions especially during times of market crisis. Also, better insights into the factors that shape market linkages can enable policy makers in assessing if a market crisis originating from across the border is likely to spill over into the domestic market. Such market disruptive behaviour also known as contagion has become an increasing risk to global financial stability, with market linkages being identified as the factor underlying the cause of such behaviour. Our findings can, therefore, assist policy makers in better devising monetary and regulatory policies, especially during times of market crisis by being able to understand the causes of these linkages.

The rest of our paper proceeds as follows. Section II provides a brief review of related literature. Section III presents our tested model while Section IV presents the empirical results and our discussions. Section V concludes the paper.

\section{Literature Review}

According to Hofstede (1980), 'culture is a collective programming of the mind which distinguishes the members of one human group from another.' Hofstede states that certain dimensions can explain the values of a particular culture and its effects on the workplace, the organization and investors. Other than Hofstede, there are a few other studies, which provide alternative definitions of culture, such as Sekely and Collins (1988), Schwartz (1992), De Jong and Semenov (2002), Tabellini (2008) and Breuer and Quinten (2009). We use the Hofstede’s framework since it is not only comprehensive, encompassing several dimensions of culture, but also offers a rich dataset covering an extensive array of countries over a long period. The benefits of Hofstede's culture dimensions over alternative measures of culture are well documented in studies such as Sondergaard (1994), Dahl (2004), and Magnussen et al. (2008). 
Several studies document the role culture plays in the evolution of financial markets. The importance of culture in the development of economic institutions dates back to Weber (1930), who argues that certain cultures are more supportive of financial markets than others. Lal (1999) points to certain traits such as individualism behind the success of western economies, in particular, their capital markets while Dutta and Mukherjee (2011) states that the uncertainty dimension significantly influences the level of financial development. Similarly, De Jong and Semenov (2002) find that the equity markets tend to be more developed if characterised with lower levels of uncertainty avoidance and higher levels of masculinity.

Culture is not only a factor in the development of financial markets, but it can also influence how investors allocate their portfolios. Hogg and Abrams (1988) claim that social conformity such as religion and nationality are not only important determinants of a group's personal identity and dominant behavioural traits but can also determine where investors choose to invest. The investor behaviour known as the home equity bias discourages investors from holding foreign equity even when they are unrestricted from holding foreign assets. It contradicts the International Capital Asset Pricing Model (ICAPM) by Solnik (1974), which states that nations are expected to hold identical portfolios and that behavioural preferences do not sway the market participants. Some studies document this bias. French and Poterba (1991) find that the investors in developed countries expect domestic returns to be higher and less risky than international markets, leading to a preference for investment in the domestic sector. They find that the local investors in the US allocate around 94\% of their investments in domestic securities, even though the US share of the global equity market was less than $48 \%$. Similarly, other markets such as Japan, Germany, France and the UK report higher domestic allocation. Other studies such as Beugelsdijk and Frijns (2010) find similar bias against foreign investments amongst domestic investors. Some studies provide reasons for this bias. Tesar and Werner (1995) state that instead of portfolio diversification motives, trade linkages and language matter more in explaining the home equity bias. They find that investors tend to shy away from foreign investment due to the higher transaction cost of investing in overseas markets. Another contributing factor to this bias is the information asymmetry, which allows local investors to profit from locally available information not available to foreign investors (Nieuwerburgh and Veldkamp, 2009).

Several other non-economic determinants of market linkages are also determined. Countries sharing a common border tend to exhibit similar culture traits along with economic and legal systems. Eun and Shim (1989) find that the correlation between stock markets in 
developed countries increases as the physical distance between them declines. Other studies by Flavin et al. (2002) and Portes and Rey (2005) conclude that geographic factors such as physical distance influence market linkages. The legal protection of investors is also identified as an important contributor to the development of equity markets by La Porta et al. (1997). They argue that countries with common law legal code tend to be more investor friendly and are more likely to have developed equity markets and exhibit higher market linkages.

A few studies investigate the impact of culture on stock market linkages. King et al. (1994) argue that unobservable factors such as investor sentiment rather than observable economic factors influence stock market correlations. Stulz and Williamson (2003) hypothesise that given that physiological factors impact the area of finance in general, culture traits also impact financial markets. Another study by Teiletche et al. (2008) does not find language, a culture variable, to be a determinant of extreme dependency in financial markets. Lucey and Zhang (2009) incorporate culture variables in their model to estimate the determinants of stock market correlations. They find that country-pair correlations with smaller culture distances depict higher linkages and also the impact of culture increases with market liquidity. However, they limit their study to the emerging markets and do not estimate the changes in the determinants over time or across regions.

\section{Data and Methodology}

The weekly logarithmic returns of 25 stock markets are used to calculate the pairwise stock market correlations, which we use as a proxy to define market linkages (Table 1 ). ${ }^{4}$ The use of weekly price index frequency avoids the problem of non-synchronous trading compared to daily returns. Also, compared to the monthly returns, it allows us to retain a relatively large number of observations for our model. The data is retrieved using the weekly MSCI country market index from the Thomson Reuters DataStream. Instead of using a common currency, local currency data is used to reflect price fluctuations in stock markets accurately. The period covered is from January 1997 to December 2013.

\footnotetext{
${ }^{4}$ To overcome the shortcoming of previous studies such as Lucey and Zhang (2009) who uses only the emerging markets in their analysis and to provide a good representation of markets across the world, stock market data from 25 markets across three regions are used. The use of a wide range of global markets can prevent bias in our results. For example, the emerging markets tend to be more segmented than the developed markets and can lead to biased results if the study is limited to such markets (Bekaert et al., 2011). The markets used in our paper account for approximately 89\% of global stock market capitalization (Source: World Development Indicators World Bank).
} 
We employ a quantile regression model instead of an OLS model since it provides a better description of the conditional distribution and offers a robust model, which is nonparametric and assumes no underlying distribution. A quantile regression model allows for a deeper insight into the relationship between culture and market linkages since it focuses not only on the conditional median but also on different conditional quantiles and is more suitable where the data depicts fat tails and outliers, commonly observed with financial market data (Koenker and Bassett, 1978). Also, given that market crisis events can lead to the market returns being skewed toward the left tail, taking this tail distribution into account provides better results (Allen et al., 2009).

Although we use the median quantile (q50) as the base estimate in our paper, we also estimate our model at the upper (q75) and the lower quantile (q25) to measure the change in determinants under various market conditions similar to other studies such as Mesi et al. (2014). These estimates can help us understand how the parameter estimates change at higher and lower levels of market linkages. The model is depicted as follows:

$$
\mathrm{Y}_{\mathrm{ij}, \mathrm{t}}=\alpha+\beta_{1}^{\prime} \mathrm{KS}_{\mathrm{ij}, \mathrm{t}}+\beta_{2}^{\prime} \text { Controls }_{\mathrm{ij}, \mathrm{t}-1}+\varepsilon_{\mathrm{ij}, \mathrm{t}}
$$

where $Y_{i j, t}$ are bilateral conditional correlations of market returns, and Controls $_{i j, t-1}$ is a vector of control variables.

Instead of measuring individual Hofstede's dimensions (Hofstede, 2001), we use a composite distance index, $K S$, as developed by Kogut and Singh (1998). This measure is commonly used to measure culture distance (Chui et al., 2002; Aggarwal et al., 2012). The larger the measure, the greater the culture distance between two markets, $i$ and $j$. This measure is depicted as:

$$
\mathrm{KS}_{\mathrm{ij}, \mathrm{t}}=\sum_{\mathrm{c}=1}^{6}\left[\left(\mathrm{I}_{\mathrm{ci}}-\mathrm{I}_{\mathrm{cj}}\right)^{2} / \mathrm{V}_{c}\right] / 6
$$

where $I_{c i}$ is the score for the $c^{\text {th }}$ cultural dimension of country $i$, $I_{c j}$ is the score for the $c^{\text {th }}$ cultural dimension of country $j$, and $V_{c}$ is the variance of the $c^{\text {th }}$ cultural dimension across all countries in the sample.

The expected sign for the variable $K S_{i j, t}$ is negative; i.e. the higher the cultural distance, the lower is the correlation between the two markets. The theoretical reasoning for this is that markets with common culture traits are likely to exhibit strong linkages. Hofstede (2001) 
identifies several dimensions on which national cultures differ and allocates a score to each of these dimensions. These national scores range from almost zero to slightly more than 100 . The dimensions ${ }^{5}$ used in Equation (2) are explained as follows:

a. Power Distance Index (PDI): Power distance refers to the extent to which the society accepts the inequality in the authority within its organizations and its entire entity (De Jong and Semenov, 2002). Individuals in countries with a large power distance tend to believe that inequality is existential, and managers are willing to pursue high returns to justify their independence (Lucey and Zhang, 2009). Such societies are characterised by concentrated power and wealth and are likely to have developed capital markets (Aggarwal and Goodell, 2010; Jessop et al., 2015). Malaysia has the largest power distance, and Denmark has the lowest one in this category.

b. Individualism versus Collectivism (IDV): As opposed to collectivism, individualism indicates whether individuals look after themselves and their immediate family versus society as a whole. This trait can lead to overconfidence amongst investors, encouraging them to underestimate the riskiness of foreign investments and allocating a higher proportion of their portfolio of international investments (Aggarwal et al., 2009; Chui et al., 2010; Beugelsdijk and Frijns, 2010). The highest score in this category goes to the US, and Indonesia scores the lowest score.

c. Masculinity versus Femininity (MAS): Masculine societies lay emphasis on achievement and success instead of caring for others and quality of life. Such societies encourage competition and reward those who are strong and are more likely to believe in a market-based system. They are also likely to support higher risk in investments and are open to foreign investments (De Jong and Semenov, 2002; Anderson et al., 2009; Jessop et al., 2015). In contrast, feminine societies tend to value equality and solidarity and prioritize individuals that need help. Japan scores the highest, whereas Sweden scores the lowest in this category.

d. Uncertainty Avoidance Index (UAI): Societies with high uncertainty avoidance feel threatened by uncertainty and ambiguity. Individuals in such societies perceive uncertainty as a constant threat and are motivated by security more than by their achievements, encouraging them to accept investment strategies with lower risks

5 These dimensions are defined as per Hofstede's personal website, available at: $\underline{\text { http://geert- }}$ hofstede.com/countries.html, retrieved on May 4, 2014. 
(Offermann and Hellmann, 1997; Dutta and Mukherjee, 2001). They are likely to prefer safer domestic investments over foreign investments leading to lower market linkages (Anderson et al., 2009; Beugelsdijk and Frijns, 2010). Greece scores the highest and, by contrast, Singapore has the lowest uncertainty avoidance score.

e. Long-Term Orientation versus Short-Term Normative Orientation (LTO): In long-term oriented or pragmatic societies, individuals believe that it is futile to fully understand the complexities of life and tend not to question rules and regulations. They are likely to prefer safety over risky investments. China has the highest score in this category, whereas Argentina has the lowest.

f. Indulgence versus Restraint (IND): This dimension refers to the extent to which individuals try to control their desires and impulses, based on their upbringing. Individuals in societies with high indulgence tend to have a relatively weak control over their impulses, compared to those in societies with low indulgence with a fairly strong control over their urges. Mexico tops the score in this category, whereas Hong Kong comes last.

The control variables Controls $_{i j, t-1}$ are defined as follows:

a. Geographic Distance (DIS): This variable refers to the logarithmic distance measured in kilometres, using the metric as the crow flies, between the capital cities of the countries. The expected sign of this variable is negative; i.e. the higher the geographic distance between the market pairs, $i$ and $j$, the lower the linkages and vice-versa (Lucey and Zhang, 2009). Data Source: Google Maps. ${ }^{6}$

b. Religion (REL): A dummy variables with values of $(1,0)$ is used to denote whether the correlation pair has a common religion - Buddhism, Christianity, ${ }^{7}$ Hinduism, and Islam. This culture variable takes the value of 1 to indicate similar religion in the two markets, and 0 otherwise. The expected sign for this variable is positive due to the possible similarity in risk averseness; i.e. common religious belief is supposed to increase market linkages (La Porta et al., 1997; Lucey and Zhang, 2009). Data Source: World Factbook. ${ }^{8}$

c. Regional proximity (REG): A dummy variable with values of $(1,0)$ is used to denote whether the markets are located in the same region - Asia-Pacific, North America, and

\footnotetext{
${ }^{6}$ Available at https://www.google.ca/maps?source=tldsi\&hl=en, retrieved on June 4, 2015.

${ }^{7}$ Christianity is divided into three sub-categories - Catholic, Protestant and Orthodox.

${ }^{8}$ Available at: https://www.cia.gov/library/publications/the-world-factbook/, retrieved on June 4, 2015.
} 
Europe. The variable takes the value of 1 if the markets are located in the same region and 0 otherwise. Markets in common regions are expected to exhibit strong linkages due to policy coordination or simply due to contagion factor because of the investors' treating the asset markets within a region as one asset class (Pretorius, 2002). The expected sign for this variable is negative; i.e. markets in common areas are likely to depict higher correlations (Lucey and Zhang, 2009). Data Source: Google Maps.

d. Legal Origin (LEG): A dummy variable with values of $(1,0)$ is used to denote whether the correlation pair has the same legal code - civil or common legal code. The variables take the value of 1 if the markets have the same legal origin and 0 otherwise. The expected sign for this variable is positive; i.e. markets with similar legal code are more likely to depict linkages. Data Source: La Porta et al. (1999).

e. Legal Enforcement of Contracts (LEGCT): Stronger legal protection and its enforcement are identified as contributing factors to market development (La Porta, 1997). This variable refers to the absolute value of the difference in the index of Legal Structure and Security of Property Rights between countries $i$ and $j .{ }^{9}$ The score ranges from 0 to 10 , with a higher score suggesting better enforcement and adequate protection of property rights, a market characteristic, which is highly sought out by foreign investors. The expected sign for this variable can be either positive or negative (Lucey and Zhang, 2009). Data Source: Economic Freedom of the World 2014 Annual Report, Fraser Institute. ${ }^{10}$

f. Annual difference in the Gross Domestic Product growth rate (GDP): This economic variable refers to the absolute value of the difference in the annual GDP growth rate between countries $i$ and $j$. Similar economic structures between markets are expected to increase market linkages (Pretorius, 2002). The expected sign for this variable is negative; i.e. an increase in the difference in GDP growth rate between two markets is likely to decrease stock market correlations between them (Lucey and Zhang, 2009). Data Source: World Bank. $^{11}$

g. Trade Linkages (RIT): Several studies document bilateral trade linkages to be a significant contributing factor to stock market linkages (Pretorius, 2002; Forbes and Chinn, 2004; Wälti, 2005). Countries with strong bilateral trade relationships are likely to

\footnotetext{
${ }^{9}$ The index includes elements such as the rule of law, security of property rights, an independent and unbiased judiciary, and impartial and effective enforcement of the law.

${ }^{10}$ Available at: http://www.freetheworld.com/release.html, retrieved on June 4, 2015.

${ }^{11}$ Available at: http://data.worldbank.org/indicator/NY.GDP.MKTP.KD.ZG, retrieved on June 4, 2015.
} 
exhibit interdependent economies and stock markets. To capture trade linkages between nations, the Regional Intensity of Trade (RIT) or the Export Intensity Index are used, based on the existing trade flows, i.e. the extent to which countries trade with each other more intensely than in other countries. The following equation depicts this index:

$$
\operatorname{RIT}_{\mathrm{J}}^{\mathrm{I}}=\frac{\mathrm{X}_{\mathrm{J}}^{\mathrm{i}} / \mathrm{X}^{\mathrm{i}}}{\mathrm{X}_{\mathrm{J}}^{\mathrm{w}} / \mathrm{X}^{\mathrm{w}}}
$$

where $X_{J}^{i}$ is country i's exports to country $j$,

$X^{i}$ is country $i$ 's total exports,

$X_{J}^{w}$ is world exports to country $j$, and

$X^{w}$ refers to total world exports.

The RIT index higher than one means that the trade flow between countries is larger than expected, given their importance in global trade. We expect the sign of this variable to be positive. Data Source: UN Trade Statistics. ${ }^{12}$

h. LANG: A dummy variable with values of $(1,0)$ is used to denote whether a common language characterizes the correlation pair. This culture variable takes the value of 1 to indicate similarity of language between the two markets, and 0 otherwise. Language is used as one of the variables to define culture since common language can increase economic linkages and investor preferences (Sekely and Collins, 1988; Grinblatt and Keloharju, 2001; Rauch, 2001). The expected sign of this variable is positive as markets with similar language are likely to depict higher linkages. Data Source: CIA Handbook. ${ }^{13}$ To summarize, the independent variables used in the model can be grouped as the distance (DIS, REG); culture (KS, REL, LANG); legal (LEG, LEGCT) and economic (RIT, GDP) variables.

\section{Empirical Results}

\section{Descriptive statistics}

Our results indicate that the best-performing stock market in Europe is Denmark (Table 2). Mexico and Indonesia top the markets in the Americas and the Asia-Pacific region, respectively regarding market linkages. Although most markets report positive returns, some

\footnotetext{
${ }^{12}$ Available at http://comtrade.un.org/, retrieved on June 4, 2015.

${ }^{13}$ Available at https://www.cia.gov/library/publications/the-world-factbook/, retrieved on June 4, 2015.
} 
such as Greece, China, and New Zealand report negative returns over the full sample period. By regions, the highest standard deviation, a measure of volatility, is reported by Russia in Europe, Argentina in the Americas and Indonesia in the Asia-Pacific. The normality conditions can be tested using the Jarque-Bera test and the results show that the returns in all markets do not follow normal distribution patterns. Negative skewness is reported in all markets except Malaysia, and all report positive kurtosis which indicates that the asymmetric tail of all distributions extends toward more positive values. The quantiles of the market return over the full sample period against the quantiles of a normal distribution show that all the markets are characterized by non-normal patterns, indicating fat-tail risks (Appendix A). Furthermore, given that all markets report kurtosis higher than three, which is the theoretical value of the normal distribution, it can be concluded that none of the returns display normal distribution and that the data exhibits a heavy-tail distribution (Table 2). ${ }^{14}$ Thus, frequencies of outcomes are more likely to occur at the extreme negative and positive ends of the distribution. The markets report an increase in volatility during the times of market crisis in 2001 and 2008-2009 especially in the Americas and Europe (Appendix B).

\section{[Insert Table 2 here]}

Furthermore, we estimate the Variance Inflation Indicator (VIF) ${ }^{15}$ to determine if multicollinearity is an issue with the independent variables. VIF is calculated for each variable by conducting a linear regression of that variable on all the other variables, and then obtaining the $R^{2}$ from that regression. A value of VIF higher than 10 indicates the presence of multicollinearity, which is ruled out in our case based on the results presented in Table 3.

[Insert Table 3 here]

\section{Correlations}

The correlation coefficient is commonly used to measure co-movement between two time-series and can depict positive, negative or stationary relationships between the markets (Taylor and Tonks, 1989; Pretorius, 2002). Results in Table 4 identify distinct relationships between the culture variables and market correlations. The $K S$ measure is negatively correlated

\footnotetext{
${ }^{14}$ For more details, see De Carlo (1997).

${ }^{15}$ See Menard (1995) for a discussion on VIF.
} 
with market linkages; i.e. the higher the cultural distances, the lower the correlations between markets. The other two culture variables, REL and $L A N G$, are positively correlated with market linkages; i.e. similar religious beliefs and language between the markets are associated with higher linkages. The results for distance variables (DIS and REG) show that the smaller geographic distance and common regional location increases market linkages. The economic variable GDP depicts no relationship with market linkages, whereas the other economic variable, RIT, is positively related to market linkages. The legal variable $L E G$ is positively related to market linkages.

\section{[Insert Table 4 here]}

\section{Regression results}

Our model uses time-varying conditional correlations as a proxy for market linkages, which are calculated by estimating annual correlations between each market by year from 2003 to 2013. Figure 1 presents the average correlation between market pairs over the full sample period. Results show an increase in correlations during 2001 leading to a brief decline over the period 2003-2005, correlations increase starting from the year 2005 with a peak in 2008 corresponding to the global financial crisis. The correlations seem to fall after 2008 but remain slightly elevated compared to the pre-2008 period.

\section{[Insert Figure 1 here]}

The quantile regression model is estimated by regressing the conditional correlations on culture and the various control variables as depicted by Equation 2, with Table 5 presenting the results. ${ }^{16}$ We find that the culture variables, $R E L, K S$, and $L A N G$, are significant determinants of correlations between markets at the median quantile - smaller cultural distance and similar religious belief and language increase market correlation. These findings are in line with the results of Lucey and Zhang (2009) and Mobarek et al. (2014).

Furthermore, we assess how the determinants change over the various quantiles by estimating the quantile process estimates of the coefficients median quantile along with 95\% confidence intervals (Appendix C). Results show that the decrease in the culture distance (KS)

\footnotetext{
${ }^{16}$ We also estimate our model using OLS regression as in Table 9. No significant changes in the estimates and test results are observed.
} 
between markets reduces market linkages over most of the quantiles. The other two culture variables REL and LANG are both positive and significant determinants of market linkages across all quantiles. When taking the magnitude of the variables into account, we find that the language variable reports the largest coefficient, followed by religion and the culture dimension, at the median quantile.

Both the distance variables, DIS and REG, are significant determinants of market linkages across most of the quantiles. The variable DIS is a negative determinant, which means that an increase in the physical distance between markets decreases market linkages. A plausible reason for this is that a larger geographic distance can lead to higher transaction costs which, coupled with the lack of similarity in the market mechanism, reduces the linkages between the markets (Flavin et al., 2002; Zhu and Yang, 2010). Observing coefficients, we find that the geographic distance between the markets has the biggest impact on market linkages.

Surprisingly, the results for economic variables are mixed with the variable GDP not being a significant determinant at the median quantile, rejecting the hypothesis that smaller difference in GDP growth increases stock market linkages. The other economic variable, RIT, is found to be significant; i.e. countries with trade linkages are more likely to exhibit higher market linkages. However, the magnitude of this variable decline over the upper quantiles. Market with similar legal systems and better enforcement of legal contracts report stronger linkages as both the legal variables, $L E G$ and $L E G A L C T$, are significant at the median quantile.

[Insert Table 5 here]

\section{Regional Analysis}

We repeat the results by regions by grouping markets into Asia-Pacific, Europe, and the Americas to determine if the effect of culture on market linkages vary across regions. The results indicate that culture seems to be a bigger determinant of market ties in the Asia-Pacific compared to Europe and the Americas. All the three culture variables, KS, REL, and LANG, are significant in the Asia-Pacific markets (Table 6). The results indicate that the culture variables are more important in shaping market linkages in the Asia-Pacific region compared to the other two regions. The elevated role of culture in Asia-Pacific could be because the markets in the 
region are much more fragmented and are more likely to source foreign investments within the region versus globally compared to other regions. ${ }^{17}$

The distance variable, DIS, is significant in all three regions and ranked higher than other variables regarding the magnitude of their coefficients. The legal variables are not significant in Asia-Pacific whereas the $L E G$ and $L E G A L C T$ variables are significant only at the $10 \%$ level in Europe and the Americas, respectively. Results for economic variables indicate that trade linkages matter more than the differences in the economic growth. The RIT variable is significant in both Asia-Pacific and Europe whereas the GDP variable fails to be a significant determinant of market linkages in all three regions.

[Insert Table 6 here]

\section{Time-Variant Analysis}

The time-varying nature of stock market linkages is widely documented in the literature (Longin and Solnik, 2001; Caporale et al., 2005; Bekaert, 2005). According to the crisiscontingent models, investor behaviour after a market crisis can lead to a tightening of market linkages. Studies such as Masson (1998) and Caporale et al. (2005) find that the investor sentiment shifts from positive to negative during market turbulence, which leads to the behaviour of herding. The propensity to engage in such behaviour can put negative pressure on other stock markets (Kaminsky and Schmukler, 1999). Our data show that the periods of market crisis such as the 2008 global financial crisis are associated with high levels of volatility and elevated levels of correlations (Figure 1). We test if the determinants of market linkages change over economic cycles by classifying the data into two periods as follows:

- Period of Calm: pre-2001 recession period (1997-2000), pre-2008 recession period (2003-2007) and post-2008 recession period (2010-2013).

- Period of Turbulence: 2001 recession (2001) and 2008 recession period (2008-2009). ${ }^{18}$

The results in Table 7a show that the culture variable, $K S$, is significant in the period of turbulence but not during the period of calm. Thus, markets with similar cultural traits during the turbulence tend to move together compared to the period of calm. The other two culture

\footnotetext{
${ }^{17}$ Source: Kim et al. (2006), Garcia-Herrero and Wooldridge (2007).

${ }^{18}$ The timeline for the recessions is as per NBER - available at http://www.nber.org/cycles/cyclesmain.html, retrieved on December 6, 2014. The timelines of the recessions are based on the US business cycles of expansion and contraction due to the fact that the US recessions were global in nature and affected markets around the globe.
} 
variables, REL and $L A N G$, are significant determinants of market linkages in both periods. Our results show that the significance of common culture and religion remains intact during times of crisis whereas the culture distance loses its impact during periods of calm. Given that all the three culture variables are significant in the period of turbulence, we can conclude that culture remains a significant determinant of market linkages during times of turmoil and is not impacted by the increase in volatility during such periods. Thus, the hypothesis that behavioural factors such as culture can lose their impact on market linkages during the times of market turbulence can be rejected.

It is also interesting to validate if the role of culture on market linkages vary across regions during periods of calm and turbulence. For example, the market volatility during the 2001 and 2008 recessions was greater in the Americas and Europe compared to the AsiaPacific. To observe these difference, we study the impact of market turbulence in the AsiaPacific region and the combined Americas and European regions. We also estimate the determinants of market linkages during times of crisis by regions as depicted in Table $7 \mathrm{~b}$. We find that the culture dimension, $K S$, is significant in the Americas-Europe but not in AsiaPacific. The differential impact is also observed with the other two culture variables. Whereas both REL and LANG are significant in Asia-Pacific, they are not significant in the other two combined regions.

[Insert Table 7a here]

[Insert Table 7b here]

\section{Active vs. Thin Markets}

Markets with infrequent trading and low trading volumes, which are associated with underdeveloped markets and high transaction costs, exhibit higher serial correlation compared to those with higher liquidity (Harvey, 1995; Levine, 1996; and Kawakatsu and Morey, 1999). According to Grinblatt and Keloharju (2001), the influence of culture disappears in markets characterised by sophisticated and institutional investors. Thus, liquid markets are likely to encourage efficiency in the allocation of capital and greater participation by investors in market trading activities. We thus test the hypothesis that market liquidity improves market efficiency leading to a diminished role of behavioural determinants such as culture in shaping market 
linkages. ${ }^{19}$ To do so, we classify the markets by liquidity, which is measured using the turnover ratio - total value of shares traded during the period divided by the average market capitalization for the period. The average market capitalization is calculated as the average of the end-of-period values for the current period and the previous period. Figure 2 presents the turnover ratios for the different markets covered in this paper. ${ }^{20}$ The markets with above average turnover ratio are classified as active and those below average as thin as follows:

- Active Markets: Korea, USA, China, Italy, Germany, Japan, France, Norway, Sweden, India, UK, Switzerland.

- Thin Markets: Australia, Canada, Denmark, Hong Kong, Singapore, Brazil, Russia, Greece, Indonesia, Malaysia, Mexico, New Zealand, Argentina.

According to Figure 2, Korea reports the highest turnover ratio with Argentina the lowest. The majority of the markets in the Americas and Asia-Pacific are classified as thin whereas most in Europe are active markets. The thin markets, with lower turnover, report higher weekly return, but higher standard deviations compared to the active markets. Also, on average, the active markets report a negative skewness and a higher kurtosis compared to the thin markets.

[Insert Figure 2 here]

We find that all three culture variables are significant in active markets, whereas the $K S$ variable is not significant in the thin markets. Thus, similar language and religion increase market linkages irrespective of market liquidity, whereas the culture distance matters only in the active markets. The decline in the magnitude of the $L A N G$ and $R E L$ variables in active markets points to the reduced role of these culture variables on market linkages. The results show that despite higher liquidity, culture variables continue to determine market linkages.

[Insert Table 8 here]

\section{Culture Blocs}

Several studies point to strong market linkages between markets sharing common cultural traits or colonial origin (Jawadi et al., 2000; Chen et al., 2002; Forbes and Chin, 2004).

\footnotetext{
${ }^{19}$ The consensus in the literature is that the increase in market linkages allows for transparency of pricing, builds investor confidence and allows market participants to efficiently raise capital across borders (Harvey et al., 1994; Beck et al., 2000; Erdogan 2009).

${ }^{20}$ A study by Lucey and Zhang (2009) finds culture variables such as religion not to be a significant determinant of correlations amongst thin trading markets. A major shortcoming of this study is that it uses the stock market capitalization ratio as a proxy for market liquidity. This measure fails to identify liquidity and can only be used to classify markets according to market size.
} 
To measure if shared common identity influences the determinants of market linkages, we group the markets into what we term as culture blocs: Anglo-Saxon (the UK, Canada, Australia and New Zealand); Latin (Mexico, Brazil, and Argentina); and Chinese (China, Hong Kong and Singapore). We assign dummy variables to denote the market pair location in common culture block. Results show that the markets within the culture blocs are more likely to depict a strong relationship between the culture distance and market linkages. For example, the culture distance within the Anglo-Saxon and the Latin blocs is a significant determinant of market linkages. Thus, common shared history and culture are likely to be a factor in shaping market linkages.

[Insert Table 10 here]

\section{Conclusion}

In this paper, we provide a comprehensive examination of how culture affects stock market linkages and extend our model to study the impact across regions, market liquidity and different economic conditions controlling for the impact of other variables. Our paper addresses several gaps in the existing literature. First, we address the role of culture as a determinant of market linkages. Our results indicate that smaller cultural distance and similar religious belief and language increase market linkages. Cultural similarities between market pairs are also likely to increase the importance of culture distance in determining market linkages. Second, we conduct a regional analysis to assess if the significance of the determinants changes across regions. Our results indicate that culture has a greater impact on market linkages in the AsiaPacific followed by Europe and the Americas. Third, we use a time-variant analysis to assess whether the significance of variables varies between times of turbulence and calm. Results indicate that most of the culture variables remain significant determinants of market linkages in both periods of calm and turbulence, implying that the volatility during times of turbulence does not impact the significance of culture as a determinant of market linkages. However, culture dimensions do lose its significance during periods of normal market behaviour. Lastly, the role of liquidity is investigated by testing if market efficiency in active markets reduces the role of culture in shaping market linkages. Our results demonstrate that liquidity in the stock market does not have a bearing on market linkages.

In general, the results show that the determinants such as culture distance, religion and language continue to affect investment behaviour, leading to market linkages. Even when we 
observe markets with high trading volume, these determinants continue to hold, which signifies that behavioural traits continue to distort market efficiency and encourage irrational markets during times of market crisis. Such behavioural biases where the market participants are likely to trade on noise can lead to severe market losses and cause immense damage to economic prosperity. Although the increase in market efficiency due to factors such as information transmission and capital mobility is likely to decrease the distortion in market behaviour by culture traits, these behavioural traits are not likely to cease to exist. Policy makers and finance practitioners need to take these factors into account if they are to optimise their policies and portfolios, respectively. 


\section{References}

Aggarwal, R., Kearney, C., and Lucey, B. (2009), “Is gravity a cultural artifact? The role of cultural distance in foreign portfolio investment," Working Paper (SSRN).

Aggarwal, R., and Goodell, J. (2010), "Financial markets versus institutions in European countries: Influence of culture and other national characteristics,” International Business Review, vol.19, pp.502-520.

Aggarwal, R., Kearney, C., and Lucey, B. (2012), “Gravity and culture in foreign portfolio investment,” Journal of Banking and Finance, vol.36 (2), pp.525-538.

Allen, D.E., Gerrans, P., Singh, A. K., and Powell, R. (2009), “Quantile regression: its application in investment analysis,” The Finsia Journal of Applied Finance, vol.4, pp.7-11.

Anderson, C.W., Fedenia, M., Hirschey, M., and Rantala, H. (2009), “There's no place like home: cultural influences on international diversification by institutional investor," Working paper, University of Kansas.

Bartram, S. M., and Wang, Y-H. (2011), "European Financial Market Integration in the Wake of the Sovereign Debt Crisis: An Industry Analysis,” 24th Australasian Finance and Banking Conference.

Beck, T., Levine, R., and Loayza, L. (2000), "Finance and the sources of growth,” Journal of Financial Economics, vol.58, pp.261-300.

Bekaert, G., Harvey, C.R., and Lundblad, C. (2005), “Does financial liberalization spur growth?” Journal of Financial Economics, vol.77 (1), pp.3-55.

Bekaert G., Lundblad, C., and Stephan, S. (2011), "What segments equity markets?,” Review of Financial Studies, vol.24 (1), pp.3841-3890

Beugelsdijk, S., and Frijns, B. (2010), “A cultural explanation of the foreign bias in international asset allocation,” Journal of Banking and Finance, vol.34, pp.2121-2131.

Boortz, C., and Jurkatis, S. (2013), "Herding in Financial markets: Bridging the gap between theory and evidence," SFB 649 Discussion Paper, vol. 2013-036.

Breuer, W., and Quinten, B. (2009), “Cultural Finance,” Working Paper (SSRN).

Caporale, G.M., Cipollini, A., and Spagnolo, N. (2005), "Testing for Contagion: A Conditional Correlation Analysis,” Journal of Empirical Finance, vol.12, pp.476-489.

Cavaglia, S., Cho, D., and Singer, B. (2001), "Risks of Sector Rotation Strategies," The Journal of Portfolio Management, vol.27 (4), pp.35-44.

Chen, G-M., Frith, M., and Rui, O.M. (2002), “Stock market linkages: Evidence from Latin America," Journal of Banking and Finance, vol. 6(6), pp. 1113-1141.

Chui, A., Titman, S., and Wei, J. (2010), “Individualism and momentum around the world,” Journal of Finance, vol.65, pp.361-392.

Chui, A.C.W., Lloyd, A.E., and Kwok, C.C.Y., (2002), “The determination of capital structure: is national culture a missing piece of the puzzle?” Journal of International Business Studies, vol.33 (1), pp.99-127.

Danareksa Research Institute (2004), “Toward a regional financial architecture for East Asia," Report commissioned by ASEAN Secretariat.

Dahl, S. (2004), “Intercultural Research: The Current State of Knowledge,” Middlesex University Discussion Paper 26, Business School, London, UK.

De Carlo, L.T. (1997), “On the meaning and use of Kurtosis,” Psychological Methods, vol.2 (3), pp.292-307.

Demirgiic-Kunt, A., and Levine, R. (1996), "Stock Markets, Corporate Finance, and Economic Growth: An Overview,” The World Bank Economic Review, vol.10 (2), pp.223-239.

De Jong, E., and Semenov, R. (2002), “Cross-country differences in stock market development: A cultural view," EFA 2002 Berlin Meetings, Presented Paper.

Dutta, N., and Mukherjee, D. (2001), “Is culture a determinant of financial development?” Applied Economics Letters, vol.19 (6), pp.585-590.

Erdogan, B. (2009), "How does European stock market integration affect the European stock markets,” Working Paper, German Institute for Economic Research.

Eun, C.S., and Shim, S. (1989), “International Transmission of Stock Market Movements,” The Journal of Financial and Quantitative Analysis, vol.24 (2), pp.241-256.

Flavin, T.J., Hurley, M.J., and Rousseau, F. (2002), "Explaining Stock Market Correlation: A Gravity Model Approach,” The Manchester School, vol.70 (S1), pp.87-106.

Forbes, K.J. (2002), “Are Trade Linkages Important Determinants of Country Vulnerability to Crises?” In Preventing Currency Crisis in Emerging Markets, University of Chicago Press, pp.2223-2261.

Forbes K.J. and Chinn, M.D. (2004), “A Decomposition of global linkages in financial markets over time,” Review of Economics and Statistics, vol.86, pp.705-722.

French, K.R., and Poterba, J.M. (1991), "Investor diversification and international equity markets," American Economic Review, vol.81, pp.222-26.

Garcia-Herrero, A., and Wooldridge, P. (2007), “Global and regional financial integration: progress in emerging markets,” BIS Quarterly Review, Bank for International Settlements. 
Gallagher, L. (1995), “Interdependencies among the Irish, British and German Stock Markets,” The Economic and Social Review, vol.26 (2), January, pp.131-147.

Grinblatt, M., and Keloharju, M. (2001), "How distance, language, and culture influence stockholdings and trades, “Journal of Finance, vol.56, pp.1053-1073.

Hardouvelis, G.A., Malliaropulos, D., and Priestley, R. (2006), “EMU and European Stock market integration,” Journal of Business, vol.79, pp.356-392.

Harvey, C. (1995), "Predictable risk and returns in emerging markets,” Review of Financial Studies, vol.8, pp. 773-816.

Hofstede, G.H. (2001), Culture’s Consequences, Sage, Beverly Hills: CA, second edition.

Hofstede, G.H. (1980), “Culture’s Consequences: International Differences in Work-Related Values,” Sage Publications, Beverly Hills: CA.

Hogg, M., and Abrams, D. (1988), Social identifications: A social psychology of intergroup relations and group processes, Routledge: London.

Jawadi, F., Million, N., and Arouri, M.E.H. (2009), "Stock market integration in the Latin American markets: further evidence from nonlinear modelling,” Statistical Finance, vol. 29 (1), pp. 162-168.

Jessop, B., Young, B., and Scherrer, C. (2015), Financial Cultures and Crisis Dynamics, Routledge Frontiers of Political Economy: Routledge, NY.

Kaminsky, G., and Schmuckler, S.L. (1999), "What triggers market jitters? A chronicle of the Asian crisis," Journal of International Money and Finance, vol.18, pp.537-560.

Kawakatsu, H., and Morey, M.R. (1999), "Financial liberalization and stock market efficiency: an empirical examination of nine emerging market countries,” Journal of Multinational Financial Management, vol.9, pp.353-371.

Kim, S, Lee, J.W., and Shin, K. (2006), “Regional and global financial integration in East Asia”, Korea University Discussion Paper Series, Institute of Economic Research, No.0602.

King, M., Sentana, E., and Wadhwani, S. (1994), "Volatility and links between national stock markets," Econometrica, vol.62, pp.901-933.

Knif, J., and Pynnonen, S. (1999), “Local and Global Price Memory of International Stock Markets,” Journal of International Financial Markets, Institutions, and Money, vol.9, pp.129-147.

Koenker, R., and Bassett, G. (1978), “Regression Quantiles” Econometrica, vol.46 (1), pp.33-50.

Koenker, R., and Machado, J.A.F. (1999), "Goodness of Fit and Related Inference Processes for Quantile Regression,” Journal of the American Statistical Association, vol.94 (448), pp.1296-1310.

Kogut, B., and Singh, H. (1988), “The effect of national culture on the choice of entry mode," Journal of International Business Studies, vol.19 (3), pp.411-32.

La Porta, R., Lopez-De-Silanes, A., and Vishny, R.W. (1997), “Legal Determinants of External Finance,” Journal of Finance, vol.52, pp.1131-50.

La Porta, R., Lopez-De-Silanes, F., Shleifer, A., and Vishny, R. (1999), “The quality of government,” Journal of Law, Economics, and Organization, vol.15, pp.222-279.

Lal, D. (1999), Unintended consequences: The impact of factor endowments, culture and politics on long-run economic performance, Cambridge, MIT Press.

Longin, F., and B. Solnik. (2001), "Extreme correlation of international equity markets,” Journal of Finance, vol.56, pp.649-76.

Lucey, B., and Zhang, Q. (2009), "Does cultural distance matter in international stock market comovement? Evidence from emerging economies around the world,” Emerging Markets Review, vol.11, pp.62-78.

Magnussen, P., Wilson, R.T., Zdravokovic, R., Zhou, J.X., and Westjohn, S. (2008), "Breaking the cultural clutter: A comparative assessment of multiple cultural and institutional frameworks,” International Marketing Review, vol.25 (2), pp.183-201.

Masson, P. R. (1998), “Contagion: macroeconomic models with multiple equilibria,” Journal of International Money and Finance, vol.18, pp.587-602.

Menard, S. (1995), Applied Logistic Regression Analysis: Sage University Series on Quantitative Applications in the Social Sciences, Thousand Oaks, CA: Sage.

Mobarek, A., Muradoglu, G., and Mollah, S. (2014), "Determinants of Time-Varying Co-movements Among International Stock Markets,” Paper presented at the European Financial Management Association Meeting, Rome.

Nieuwerburgh, S.V., and Veldkamp, L. (2009), “Information Immobility and home bias puzzle,” Journal of Finance, vol.64 (3), pp.1187-1215.

Offermann, L.R., and Hellmann, P.S. (1997), "Culture's consequences for leadership behavior: National values in action,” Journal of Cross-cultural Psychology, vol.28, pp.342-351.

Phillips, S.D., and Smith, S.R. (2014), “A Dawn of Convergence? Third sector policy regimes in the 'AngloSaxon’ cluster,” Public Management Review, vol. 16 (8), pp. 1141-1163. 
Pirouz, D.M., and Graham, J.L. (2010), “Culture, Globalization and stock price volatility,” Working Paper (SSRN).

Portes, R., and Rey, H. (2005), “The determinants of cross-border equity flows,” Journal of International Economics, vol.65, pp.269-296.

Pretorius, E. (2002), “Economic determinants of emerging Stock Market Interdependence,” Emerging Markets Review, vol.3, pp.84-105.

Rauch, J. E. (2001), "Business and social networks in international trade,” Journal of Economic Literature, vol.39(4), pp.1177-203.

Schwartz, S.H. (1992), "Universal in the content and structure of values: Theoretical advances and empirical tests in 20 countries,” Advances in Experimental Social Psychology, vol.25, pp.1-65.

Sekely, M.J., and Collins, W.S. (1988), “Cultural influences on international capital structure,” Journal of International Business Studies, vol.19, pp.87-100.

Solnik, B. (1974), “An equilibrium model of the international capital market,” Journal of Economic Theory, pp.8500-524.

Sondergaard, M. (1994), "Hofstede’s Consequences: A Study of Reviews, Citations, and Replications," Organizations Studies, vol.15, pp.447-456.

Stafford, D., and Miles, L. (2013), “Integrating cultures after a merger,” Bain Brief, Bain and Company.

Stahl, G., and Voigt, A. (2003), "Meta-analysis of the Performance Implications of Culture Differences in Mergers and Acquisitions: Integration Strategic, Financial, and Organizational Perspectives,” Working Paper Series, INSEAD.

Stulz, R., and Williamson, R. (2003), “Culture Openness and Finance,” Journal of Financial Economics, vol.70, pp.313-419.

Tabellini, G. (2010), “Culture and Institutions: Economic Development in the Regions of Europe,” Journal of the European Economic Association, vol.8 (4), pp.677-716.

Taylor, M.P., and Tonks, I. (1989), "The Internationalisation of Stock Markets and the Abolition of UK Exchange Control,” Review of Economics and Statistics, vol.71, pp.332-336.

Tesar, L., and Werner, I. (1995), "Home Bias and High Turnover,” Journal of International Money and Finance, vol.14, pp.467-92.

Teiletche, J., Xu, B., (2008), “The determinants of extreme dependence in financial markets,” Working Paper, Economie et Finance Internationales, Universite Montesquieu Bordeaux IV.

Wälti, S. (2005), “The macroeconomic determinants of stock market synchronization,” Department of Economics Working Paper, Trinity College Dublin, Dublin.

Weber, M. (1930), Protestant ethic and the spirit of capitalism, London: Allen and Unwin.

Zhu, L., and Yang, J. (2010), "Physic distance in the eight-year crisis: an empirical study," In Handbook of Behavioral Finance, edited by Brian R, Bruce, Edwards Edgar Publishing. 
Table 1: Regions and Countries

\begin{tabular}{ll}
\hline AMERICAS & Argentina, Brazil, Canada, Mexico, US \\
\hline ASIA-PACIFIC & Australia, China, Hong Kong, India, Japan, New Zealand, Singapore, Indonesia, Malaysia, South Korea \\
\hline EUROPE & Denmark, France, Germany, Greece, Italy, Norway, Russia, Switzerland, Sweden, UK \\
\hline
\end{tabular}


Table 2: Descriptive Analysis (Weekly returns - full sample period)

\begin{tabular}{|c|c|c|c|c|c|c|}
\hline & Mean & Median & Std. Dev. & Skewness & Kurtosis & Jarque-Bera* \\
\hline \multicolumn{7}{|c|}{ Europe } \\
\hline DN & 0.0919 & 0.1565 & 1.2333 & -1.1317 & 10.8171 & 2660.2520 \\
\hline FN & 0.0394 & 0.1060 & 1.3208 & -0.7542 & 8.3314 & 1233.0780 \\
\hline GM & 0.0427 & 0.1840 & 1.4383 & -0.6377 & 7.6241 & 924.2059 \\
\hline GR & -0.0612 & 0.0607 & 2.1516 & -0.4100 & 6.4063 & 493.0556 \\
\hline IT & 0.0179 & 0.1363 & 1.4389 & -0.8037 & 9.0744 & 1585.8660 \\
\hline NO & 0.0377 & 0.1926 & 1.4325 & -1.0346 & 10.0392 & 2162.2200 \\
\hline $\mathrm{RU}$ & 0.0661 & 0.1667 & 2.8749 & -0.0635 & 10.4252 & 2215.1980 \\
\hline SW & 0.0605 & 0.1990 & 1.4707 & -0.5221 & 7.1210 & 725.9140 \\
\hline SZ & 0.0385 & 0.1501 & 1.1823 & -1.0423 & 14.2797 & 5285.0200 \\
\hline UK & 0.0214 & 0.0828 & 1.0744 & -0.9805 & 13.3490 & 4456.3570 \\
\hline \multicolumn{7}{|c|}{ Americas } \\
\hline$A R$ & 0.0864 & 0.1648 & 2.3317 & -0.3310 & 7.2302 & 736.3607 \\
\hline BR & 0.0828 & 0.1873 & 1.7558 & -0.5429 & 7.1511 & 739.4837 \\
\hline CA & 0.0483 & 0.1502 & 1.1244 & -0.7089 & 8.8430 & 1452.0650 \\
\hline$M X$ & 0.1103 & 0.1838 & 1.4437 & -0.1984 & 7.3034 & 750.1913 \\
\hline US & 0.0468 & 0.0971 & 1.1010 & -0.7380 & 9.1322 & 1597.9350 \\
\hline \multicolumn{7}{|c|}{ Asia-Pacific } \\
\hline$A U$ & 0.0386 & 0.1172 & 0.9270 & -0.7957 & 8.1065 & 1149.1400 \\
\hline $\mathrm{CN}$ & -0.0002 & 0.1172 & 1.9959 & -0.3586 & 6.0841 & 402.7232 \\
\hline HK & 0.0262 & 0.1061 & 1.4566 & -0.5233 & 6.6655 & 583.6741 \\
\hline IN & 0.0987 & 0.2333 & 1.5344 & -0.4144 & 5.4846 & 275.5482 \\
\hline$J P$ & 0.0054 & 0.0764 & 1.2374 & -0.7138 & 7.0688 & 746.8206 \\
\hline NZ & -0.0048 & 0.0389 & 0.9668 & -0.2525 & 5.6982 & 302.6774 \\
\hline SG & 0.0186 & 0.0619 & 1.3273 & -0.5141 & 10.0165 & 2019.8970 \\
\hline ID & 0.0821 & 0.1653 & 2.0801 & -0.0658 & 8.6252 & 1271.6960 \\
\hline MY & 0.0140 & 0.0805 & 1.3553 & 0.2034 & 14.2181 & 5061.4690 \\
\hline $\mathrm{KR}$ & 0.0699 & 0.1380 & 1.8718 & -0.2761 & 6.2768 & 443.5450 \\
\hline
\end{tabular}

Note: Argentina (AR), Australia (AU), Brazil (BR), Canada(CA), China(CN), Denmark (DN), France (FN), Germany (GM), Greece (GR), Hong Kong (HK), India (IN), Indonesia (ID), Italy (IT), Japan (JP), South Korea (KR), Malaysia (MY), Mexico (MX), Norway (NO), New Zealand (NZ), Russia (RU), Singapore (SG), Sweden (SW), Switzerland (SZ), United Kingdom (UK), United States of America (US).

* The JB test are significant at the $5 \%$ level for all markets. 
Table 3: Multicollinearity test

\begin{tabular}{|c|c|c|}
\hline Variables & VIF & 1/VIF \\
\hline DIS & 2.30 & 0.4352 \\
\hline REG & 2.26 & 0.4433 \\
\hline$K S$ & 1.22 & 0.8188 \\
\hline$R E L$ & 1.23 & 0.8160 \\
\hline RIT & 1.10 & 0.9070 \\
\hline LANG & 1.07 & 0.9372 \\
\hline$L E G$ & 1.02 & 0.9776 \\
\hline LEGALCT & 1.00 & 0.9950 \\
\hline GDP & 1.00 & 0.9999 \\
\hline Mean VIF & 1.36 & \\
\hline
\end{tabular}


Table 4: Correlations

\begin{tabular}{|c|c|c|c|c|c|c|c|c|c|c|}
\hline Variables & COR & DIS & $G D P$ & $K S$ & $L E G$ & LEGALCT & $R E G$ & $R E L$ & $R I T$ & LANG \\
\hline COR & 1.00 & & & & & & & & & \\
\hline$D I S$ & -0.32 & 1.00 & & & & & & & & \\
\hline GDP & 0.00 & 0.00 & 1.00 & & & & & & & \\
\hline$K S$ & -0.13 & 0.19 & 0.00 & 1.00 & & & & & & \\
\hline$L E G$ & 0.09 & -0.03 & -0.002 & -0.21 & 1.00 & & & & & \\
\hline LEGALCT & -0.01 & -0.06 & 0.00 & -0.09 & 0.09 & 1.00 & & & & \\
\hline$R E G$ & 0.03 & 0.02 & 0.01 & -0.04 & -0.01 & 0.01 & 1.00 & & & \\
\hline$R E L$ & 0.17 & -0.73 & -0.005 & -0.10 & 0.11 & 0.00 & -0.03 & 1.00 & & \\
\hline$R I T$ & 0.18 & -0.25 & 0.012 & -0.37 & 0.11 & 0.00 & -0.02 & 0.21 & 1.00 & \\
\hline LANG & 0.02 & -0.25 & -0.004 & -0.15 & 0.11 & 0.08 & 0.04 & 0.24 & 0.14 & 1.00 \\
\hline
\end{tabular}

Note: The variables are defined as Market Correlation (COR); Geographic distance (DIS); Annual difference in Gross Domestic Product growth rate (GDP); Culture distance developed by Kogut and Singh (1998) (KS); Legal origin (LEG); Legal enforcement of contracts (LEGALCT); Regional proximity (REG); Religion (REL); Trade linkages (RIT); Language (LANG). 
Table 5: Quantile Regression results - Full sample period

\begin{tabular}{|c|c|c|c|}
\hline Independent Variables & $q 25$ & q50 & q75 \\
\hline \multirow[t]{2}{*}{ Intercept } & $1.503 * * *$ & $1.548^{* * *}$ & $1.457^{* * *}$ \\
\hline & (32.29) & $(34.73)$ & $(51.56)$ \\
\hline \multirow[t]{2}{*}{ DIS } & $-0.300 * * *$ & $-0.262 * * *$ & $-0.204 * * *$ \\
\hline & $(-26.91)$ & $(-23.49)$ & $(-27.48)$ \\
\hline \multirow[t]{2}{*}{ GDP $(x 100)$} & 0.000 & 0.000 & 0.000 \\
\hline & $(-0.11)$ & $(-0.12)$ & $(-0.08)$ \\
\hline \multirow[t]{2}{*}{$K S$} & $0.010 *$ & $-0.015^{* * *}$ & $-0.018 * * *$ \\
\hline & $(1.45)$ & $(-2.60)$ & $(-3.35)$ \\
\hline \multirow[t]{2}{*}{$L E G$} & $-0.023 * * *$ & $-0.027 * * *$ & $-0.015 * * *$ \\
\hline & $(-3.16)$ & $(-4.64)$ & $(-3.22)$ \\
\hline \multirow[t]{2}{*}{ LEGALCT } & $0.003^{* * *}$ & $0.004 * * *$ & $0.004 * * *$ \\
\hline & $(2.45)$ & (3.03) & (4.24) \\
\hline \multirow[t]{2}{*}{$R E G$} & $-0.108 * * *$ & $-0.086 * * *$ & $-0.051 * * *$ \\
\hline & $(-10.72)$ & $(-8.73$ & $(-7.49)$ \\
\hline \multirow[t]{2}{*}{$R E L$} & $0.068^{* * *}$ & $0.048^{* * *}$ & $0.036 * * *$ \\
\hline & (7.22) & $(6.20)$ & (5.89) \\
\hline \multirow[t]{2}{*}{ RIT } & $-0.010 * * *$ & $-0.011 * * *$ & $-0.007 * * *$ \\
\hline & $(-4.65)$ & $(-5.47)$ & $(-2.85)$ \\
\hline \multirow[t]{2}{*}{ LANG } & $0.101^{* * *}$ & $0.076 * * *$ & $0.047^{* * *}$ \\
\hline & (8.99) & (9.08) & (7.49) \\
\hline Pseudo $R^{2}$ & 0.073 & 0.0784 & 0.0850 \\
\hline Quasi-LR stat & $777.10 * * *$ & $1018.35^{* * *}$ & $1115.70 * * *$ \\
\hline$N$ & 10,200 & 10,200 & 10,200 \\
\hline
\end{tabular}


Table 6: Quantile Regression results - Regional Analysis

\begin{tabular}{|c|c|c|c|c|c|c|c|c|c|}
\hline \multirow{2}{*}{$\begin{array}{l}\text { Independen } \\
\text { t Variables }\end{array}$} & \multicolumn{3}{|c|}{ Americas } & \multicolumn{3}{|c|}{ Asia-Pacific } & \multicolumn{3}{|c|}{ Europe } \\
\hline & $q 25$ & q50 & q75 & $q 25$ & q50 & q75 & $q 25$ & q50 & q75 \\
\hline \multirow[t]{2}{*}{ Intercept } & $2.090 * * *$ & $1.822^{* * *}$ & $1.318^{* * *}$ & $0.888^{* * *}$ & $0.900 * * *$ & $0.858 * * *$ & $1.970 * * *$ & $1.797 * * *$ & $1.660 * * *$ \\
\hline & $(8.68)$ & (6.94) & $(8.48)$ & $(5.24)$ & $(8.72)$ & 10.56 & $(11.36)$ & $(30.96)$ & 23.23 \\
\hline \multirow[t]{2}{*}{ DIS } & $-0.442 * * *$ & $-0.308 * * *$ & $-0.146 * * *$ & $-0.179 * * *$ & $-0.114 * * *$ & $-0.050 * *$ & $-0.434 * * *$ & $-0.338 * * *$ & $-0.268 * * *$ \\
\hline & $(-6.44)$ & $(-4.52)$ & $(-3.41)$ & $(-3.76)$ & $(-3.56)$ & $(-2.12)$ & $(-7.99)$ & $(-16.17)$ & $(-10.22)$ \\
\hline \multirow[t]{2}{*}{ GDP $(x 100)$} & $0.005^{* *}$ & 0.000 & 0.003 & 0.002 & 0.001 & 0.001 & 0.001 & 0.000 & 0.001 \\
\hline & $(0.65)$ & $(-0.04)$ & $(0.77)$ & $(0.92)$ & $(0.36)$ & $(1.00)$ & $(0.42)$ & $(0.08)$ & $(0.18)$ \\
\hline \multirow[t]{2}{*}{$K S$} & -0.042 & -0.104 & $-0.091^{*}$ & 0.014 & $-0.039 * *$ & $-0.051 * * *$ & $-0.066 * * *$ & $-0.060 * * *$ & $-0.050 * * *$ \\
\hline & $(-0.59)$ & $(-1.11)$ & $(-1.70)$ & $(0.84)$ & $(-2.15)$ & $(-4.65)$ & $(-4.82)$ & $(-4.00)$ & $(-3.90)$ \\
\hline \multirow[t]{2}{*}{$L E G$} & -0.029 & -0.007 & 0.034 & -0.017 & -0.027 & $-0.049 * * *$ & -0.009 & $-0.022 *$ & -0.009 \\
\hline & -0.46 & $(-0.09)$ & $(0.71)$ & $(-0.96)$ & $(-1.53)$ & $(-4.45)$ & $(-0.45)$ & $(1.68)$ & $(0.72)$ \\
\hline \multirow[t]{2}{*}{ LEGALCT } & 0.021 & $0.018^{*}$ & $0.015^{* * *}$ & 0.000 & 0.000 & 0.002 & -0.004 & -0.002 & -0.002 \\
\hline & $(2.13)$ & $(2.49)$ & $(2.70)$ & $(-0.17)$ & $(0.12)$ & $(1.34)$ & $(-1.04)$ & $(-0.56)$ & $(-0.71)$ \\
\hline \multirow[t]{2}{*}{$R E L$} & -0.015 & -0.023 & -0.003 & $0.126 * * *$ & $0.091^{* * *}$ & $0.053^{* * *}$ & -0.001 & 0.014 & 0.018 \\
\hline & $(0.33)$ & $(-0.53)$ & $(-0.09)$ & $(5.08)$ & $(4.77)$ & $(4.42)$ & $(-0.04)$ & $(1.07)$ & (1.40) \\
\hline \multirow[t]{2}{*}{ RIT } & $-0.012^{* *}$ & -0.007 & -0.006 & $-0.008 * * *$ & $-0.013 * * *$ & $-0.008 * * *$ & $-0.038 * * *$ & $-0.033 * * *$ & $-0.028 * * *$ \\
\hline & $(-2.58)$ & $(-1.37)$ & $(-1.55)$ & $(-4.50)$ & $(-4.65)$ & $(-3.22)$ & $(-6.11)$ & $(-7.30)$ & $(-8.11)$ \\
\hline \multirow[t]{2}{*}{ LANG } & -0.060 & $-0.130 * *$ & -0.074 & $0.115^{* * *}$ & $0.089 * * *$ & $0.070 * * *$ & 0.016 & -0.014 & 0.038 \\
\hline & $(-0.96)$ & $(-2.09)$ & $(-1.60)$ & $(5.92)$ & $(3.97)$ & $(4.22)$ & $(0.52)$ & $(0.84)$ & (1.59) \\
\hline Pseudo $R^{2}$ & 0.1365 & 0.0864 & 0.0730 & 0.0659 & 0.0602 & 0.0601 & 0.1429 & 0.1449 & 0.1238 \\
\hline $\begin{array}{l}\text { Quasi-LR } \\
\text { stat }\end{array}$ & $51.02 * * *$ & $34.41 * * *$ & $31.55^{* * *}$ & $111.02 * * *$ & $107.22 * * *$ & $120.64 * * *$ & $246.18^{* * *}$ & $333.00 * * *$ & $244.56^{* * *}$ \\
\hline$N$ & 340 & 340 & 340 & 1530 & 1530 & 1530 & 1530 & 1530 & 1530 \\
\hline
\end{tabular}


Table 7a: Quantile Regression results - Period of calm vs. Period of turbulence

\begin{tabular}{|c|c|c|c|c|c|c|}
\hline \multirow[t]{2}{*}{ Independent Variables } & \multicolumn{3}{|c|}{ Period of Calm } & \multicolumn{3}{|c|}{ Period of turbulence } \\
\hline & q25 & q50 & q75 & q25 & q50 & q75 \\
\hline \multirow[t]{2}{*}{ Intercept } & $1.439 * * *$ & $1.573 * * *$ & $1.465 * * *$ & $1.517^{* * *}$ & $1.450 * * *$ & $1.411^{* * *}$ \\
\hline & $(26.35)$ & $(31.50)$ & $(41.76)$ & $(12.62)$ & $(19.66)$ & $(26.21)$ \\
\hline \multirow[t]{2}{*}{ DIS } & $-0.285^{* * *}$ & $-0.276 * * *$ & $-0.212^{* * *}$ & $-0.270 * * *$ & $-0.204 * * *$ & $-0.174 * * *$ \\
\hline & $(-21.45)$ & $(-21.76)$ & $(-24.09)$ & $(-8.50)$ & $(-10.96)$ & $(-12.61)$ \\
\hline \multirow[t]{2}{*}{ GDP $(x 100)$} & 0.000 & 0.000 & 0.000 & 0.000 & -0.001 & 0.000 \\
\hline & $(-0.19)$ & $(-0.76)$ & $(0.28)$ & $(-0.16)$ & $(-0.64)$ & $(-0.34)$ \\
\hline \multirow[t]{2}{*}{$K S$} & 0.007 & -0.008 & $-0.020 * * *$ & $0.009 * *$ & $-0.022 * *$ & $-0.027 * * *$ \\
\hline & $(0.98)$ & $(-1.57)$ & $(-4.09)$ & $(0.58)$ & $(2.26)$ & $(-4.53)$ \\
\hline \multirow[t]{2}{*}{$L E G$} & $-0.026 * * *$ & $-0.028 * * *$ & $-0.018^{* * *}$ & -0.023 & -0.017 & -0.004 \\
\hline & $(-3.91)$ & $(-4.54)$ & $(-3.32)$ & $(-1.30)$ & $(-1.63)$ & $(-0.53)$ \\
\hline \multirow[t]{2}{*}{ LEGALCT } & $0.003^{* *}$ & $0.003 * * *$ & $0.004^{* * *}$ & 0.006 & 0.003 & $0.002^{*}$ \\
\hline & $(1.96)$ & $(2.73)$ & $(4.33)$ & $(1.30)$ & $(1.45)$ & $(1.71)$ \\
\hline \multirow[t]{2}{*}{$R E G$} & $-0.094 * * *$ & $-0.098 * * *$ & $-0.053 * * *$ & $-0.103 * * *$ & $-0.047 * * *$ & -0.016 \\
\hline & $(-8.33$ & $(-9.29)$ & $(-6.01)$ & $(-3.85)$ & $(-2.61)$ & $(-1.00)$ \\
\hline \multirow[t]{2}{*}{$R E L$} & $0.070 * * *$ & $0.047 * * *$ & $0.039 * * *$ & $0.089 * * *$ & $0.026^{* *}$ & $0.017^{* *}$ \\
\hline & $(7.98)$ & $(4.82)$ & $(5.95)$ & (3.97) & $(2.20)$ & $(2.00)$ \\
\hline \multirow{2}{*}{ RIT } & $-0.009 * *$ & $-0.009 * * *$ & $-0.006 * * *$ & $-0.017 * * *$ & $-0.015^{*}$ & -0.005 \\
\hline & $(-5.05)$ & $(-4.15)$ & $(-3.23)$ & $(-2.90)$ & $(-2.87)$ & $(-0.88)$ \\
\hline \multirow[t]{2}{*}{ LANG } & $0.081 * * *$ & $0.079 * * *$ & $0.047 * * *$ & $0.153^{* * *}$ & $0.055^{* * *}$ & $0.022^{*}$ \\
\hline & $(6.65)$ & $(9.13)$ & $(-3.23)$ & $(8.16)$ & $(5.12)$ & $(1.85)$ \\
\hline Pseudo $R^{2}$ & 0.0700 & 0.0802 & 0.0861 & 0.1021 & 0.0941 & 0.1363 \\
\hline Quasi-LR stat & $652.10^{* * *}$ & $889.15^{* * *}$ & $879.30 * * *$ & $183.97 * * *$ & $259.59 * * *$ & $413.87 * * *$ \\
\hline$N$ & 8400 & 8400 & 8400 & 1800 & 1800 & 1800 \\
\hline
\end{tabular}


Table 7b: Quantile Regression results - Period of calm vs. Period of turbulence

\begin{tabular}{|c|c|c|c|c|}
\hline \multirow[t]{2}{*}{ Independent Variables } & \multicolumn{2}{|c|}{ Period of Calm } & \multicolumn{2}{|c|}{ Period of turbulence } \\
\hline & $\begin{array}{l}\text { Americas and } \\
\text { Europe }\end{array}$ & Asia Pacific & $\begin{array}{l}\text { Americas and } \\
\text { Europe }\end{array}$ & Asia Pacific \\
\hline \multirow[t]{2}{*}{ Intercept } & $1.247 * * *$ & $0.926 * * *$ & $1.337 * * *$ & $0.924 * * *$ \\
\hline & $(-26.93)$ & $(9.843)$ & $(19.40)$ & $(3.44)$ \\
\hline \multirow[t]{2}{*}{ DIS } & $-0.175 * * *$ & $-0.127 * *$ & $-0.162 * * *$ & $-0.072 * * *$ \\
\hline & $(-14.04)$ & $(-4.55)$ & $(-9.11)$ & $(-0.89)$ \\
\hline \multirow[t]{2}{*}{ GDP $(x 100)$} & 0.000 & 0.001 & -0.001 & -0.001 \\
\hline & $(-0.27)$ & $(0.40)$ & $(-0.46)$ & $(-0.17)$ \\
\hline \multirow[t]{2}{*}{$K S$} & $-0.051 * * *$ & $-0.040 * *$ & $-0.039 * * *$ & -0.057 \\
\hline & $(-5.96)$ & $(-2.19)$ & $(-2.62)$ & $(-1.33)$ \\
\hline \multirow[t]{2}{*}{$L E G$} & $-0.043 * * *$ & -0.030 & $-0.033^{* *}$ & -0.026 \\
\hline & $(-4.47)$ & $(-1.45)$ & $(-2.17)$ & $(-0.88)$ \\
\hline \multirow[t]{2}{*}{ LEGALCT } & 0.001 & 0.000 & 0.005 & -0.001 \\
\hline & -0.54 & $(0.07)$ & $(1.43)$ & $(-0.19)$ \\
\hline \multirow[t]{2}{*}{$R E L$} & $0.033 * * *$ & $0.085^{* * *}$ & 0.005 & $0.071^{* * *}$ \\
\hline & $(-3.05)$ & $(4.87)$ & $(0.35)$ & $(1.56)$ \\
\hline \multirow[t]{2}{*}{$R I T$} & $-0.010 * *$ & $-0.010 * * *$ & $-0.017 * * *$ & $-0.023 * * *$ \\
\hline & $(-2.07)$ & $(-2.89)$ & $(-4.78)$ & $(-3.67)$ \\
\hline \multirow[t]{2}{*}{ LANG } & $0.075^{* * *}$ & $0.048^{*}$ & 0.026 & $0.137^{* * *}$ \\
\hline & -5.53 & $(1.86)$ & $(1.44)$ & $(5.11)$ \\
\hline Pseudo $R^{2}$ & 0.1118 & 0.0722 & 0.1195 & 0.0969 \\
\hline Quasi-LR stat & $488.87 * * *$ & $112.98 * * *$ & $115.95 * * *$ & $37.97 * * *$ \\
\hline$N$ & 3150 & 1260 & 630 & 270 \\
\hline
\end{tabular}

Note: The table presents the quantile regression results of the model during the periods of calm and turbulence by regions. *, ** and *** denote the levels of significance at $1 \%, 5 \%$ and $10 \%$, respectively. $t$-statistics are reported in brackets. q25 refers to the first quartile (25 percentile), q50 refers to the second quartile (50 percentile) or the median, and q75 refers to the third quartile (75 percentile). The Quasi-Likelihood Ratio Test by Koenker and Machado (1999) depicts the robustness of the model. 
Table 8: Quantile Regression results - Active vs. Thin markets

\begin{tabular}{|c|c|c|c|c|c|c|}
\hline \multirow{2}{*}{ Independent Variables } & \multicolumn{3}{|c|}{ Active Markets } & \multicolumn{3}{|c|}{ Thin Markets } \\
\hline & q25 & q50 & q75 & q25 & q50 & q75 \\
\hline \multirow[t]{2}{*}{ Intercept } & $1.897 * * *$ & $1.733 * * *$ & $1.651^{* * *}$ & $1.075^{* * *}$ & $0.951 * * *$ & $0.824 * * *$ \\
\hline & $(11.07)$ & $(25.02)$ & $(25.37)$ & $(8.92)$ & $(9.54)$ & $(9.22)$ \\
\hline \multirow[t]{2}{*}{$D I S$} & $-0.383 * * *$ & $-0.304 * * *$ & $-0.254 * * *$ & $-0.203 * * *$ & $-0.132 * * *$ & $-0.054^{* *}$ \\
\hline & $(-8.67)$ & $(-16.69)$ & $(-15.05)$ & $(-6.88)$ & $(-5.49)$ & $(-2.42)$ \\
\hline \multirow[t]{2}{*}{ GDP $(x 100)$} & 0.000 & 0.000 & 0.000 & -0.002 & -0.001 & 0.000 \\
\hline & $(-0.17)$ & $(0.01)$ & $(0.12)$ & $(-1.48)$ & $(-0.91)$ & $(0.23)$ \\
\hline \multirow[t]{2}{*}{$K S$} & -0.008 & $-0.017 * *$ & $-0.016 * *$ & 0.011 & -0.003 & $-0.020 * *$ \\
\hline & $(-0.63)$ & $(-2.20)$ & $(-2.16)$ & $(0.90)$ & $(-0.30)$ & $(-2.01)$ \\
\hline \multirow[t]{2}{*}{ LEG } & $0.033 * *$ & $0.037 * * *$ & $0.024 * * *$ & $-0.040 * * *$ & -0.017 & $-0.019 *$ \\
\hline & $(2.36)$ & $(4.04)$ & $(2.87)$ & $(-3.13)$ & $(-1.41)$ & $(-1.80)$ \\
\hline \multirow[t]{2}{*}{ LEGALCT } & 0.000 & -0.002 & 0.000 & $0.008 * * *$ & $0.006 * *$ & $0.006 * * *$ \\
\hline & $(-0.00)$ & $(-1.04)$ & $(0.27)$ & $(3.01)$ & $(2.72)$ & $(3.16)$ \\
\hline \multirow[t]{2}{*}{ REG } & $-0.106 * * *$ & $-0.051^{* *}$ & $-0.046 * * *$ & $-0.087^{* * *}$ & $-0.056 * *$ & -0.009 \\
\hline & $(-2.68)$ & $(-2.54)$ & $(-2.91)$ & $(-3.67)$ & $(-2.81)$ & $(-0.51)$ \\
\hline \multirow[t]{2}{*}{ REL } & -0.015 & $0.027^{* *}$ & $0.044^{* * *}$ & $0.053^{* *}$ & $0.051 * *$ & $0.040 * * *$ \\
\hline & $(0.65)$ & $(2.21)$ & $(4.77))$ & $(2.58)$ & $(2.80)$ & $(2.63)$ \\
\hline \multirow[t]{2}{*}{$R I T$} & $-0.038 * * *$ & $-0.038 * * *$ & $-0.029 * * *$ & $-0.006 * * *$ & $-0.005 * *$ & $-0.004 * * *$ \\
\hline & $(-4.13)$ & $(-6.94)$ & $(-5.79)$ & $(-3.13)$ & $(-1.35)$ & $(2.63)$ \\
\hline \multirow[t]{2}{*}{ LANG } & 0.012 & $0.013^{* *}$ & 0.014 & $0.159 * * *$ & $0.113^{* * *}$ & $0.082 * * *$ \\
\hline & (0.47) & $(0.97)$ & $(1.00)$ & (7.13) & $(6.90)$ & $(6.52)$ \\
\hline Pseudo $R^{2}$ & 0.1301 & 0.1674 & 0.1925 & 0.0370 & 0.0301 & 0.0285 \\
\hline Quasi-LR stat & $309.15^{* * *}$ & $627.81 * * *$ & $637.11 * * *$ & $106.97 * * *$ & $97.34 * * *$ & $90.02 * * *$ \\
\hline$N$ & 2,244 & 2,244 & 2,244 & 2,652 & 2,652 & 2,652 \\
\hline
\end{tabular}

Note: The table presents the quantile regression results of the model using active and thin markets based on liquidity. $*$, $* *$ and $* * *$ denote the levels of significance at $1 \%, 5 \%$ and $10 \%$, respectively. $t$-statistics are reported in brackets. q25 is the first quartile (25 percentile), q50 is the second quartile (50 percentile) or the median, and q75 is the third quartile (75 percentile). The Quasi-Likelihood Ratio Test by Koenker and Machado (1999) depicts the robustness of the model. 
Table 9: OLS Regression results

\begin{tabular}{|c|c|c|c|c|c|c|c|c|}
\hline & $\begin{array}{l}\text { Full } \\
\text { Sample }\end{array}$ & Americas & Asia & Europe & $\begin{array}{l}\text { Calm } \\
\text { Markets }\end{array}$ & Turbulence & $\begin{array}{l}\text { Active } \\
\text { Markets }\end{array}$ & $\begin{array}{l}\text { Thin } \\
\text { Markets }\end{array}$ \\
\hline \multirow[t]{2}{*}{ Intercept } & $1.376^{* * *}$ & $1.702^{* * *}$ & $0.747 * * *$ & $1.824 * * *$ & $1.402 * * *$ & $1.633^{* * *}$ & $1.718 * * *$ & $0.865 * * *$ \\
\hline & $(43.86)$ & $(10.51)$ & $(8.21)$ & 22.54 & $(42.09)$ & (18.05) & $(22.13)$ & $(10.62)$ \\
\hline \multirow[t]{2}{*}{ DIS } & $-0.241 * * *$ & $-0.298 * * *$ & $-0.082 * * *$ & $-0.358 * * *$ & $-0.235 * * *$ & $-0.285^{* * *}$ & $-0.310 * * *$ & $-0.112^{* * *}$ \\
\hline & $(-30.84)$ & $(-6.86)$ & $(-3.13)$ & $(-13.99)$ & $(-28.47)$ & $(-12.71)$ & $(-15.48)$ & $(-5.69)$ \\
\hline \multirow[t]{2}{*}{$G D P(x 100)$} & 0.000 & 0.001 & 0.001 & 0.000 & 0.000 & -0.001 & 0.000 & -0.001 \\
\hline & $(-0.61)$ & $(0.57)$ & $(0.58)$ & $(0.16)$ & $(-0.51)$ & $(-0.42)$ & $(-0.51)$ & $(-0.79)$ \\
\hline \multirow[t]{2}{*}{$K S$} & $-0.006^{*}$ & -0.043 & $-0.023 * *$ & $-0.056 * * *$ & $-0.010 * *$ & $0.019^{*}$ & -0.009 & -0.001 \\
\hline & $(-1.66)$ & $(-0.99)$ & $(-1.98)$ & $(-6.10)$ & $(-2.42)$ & $(1.80)$ & $(-1.26)$ & $(-0.11)$ \\
\hline \multirow[t]{2}{*}{$L E G$} & $-0.019 * * *$ & -0.001 & $-0.027 * *$ & -0.011 & $-0.022 * * *$ & 0.001 & $0.027 * * *$ & -0.017 \\
\hline & $(-4.72)$ & $(0.04)$ & $(-2.25)$ & $(0.50)$ & $(-5.08)$ & $(0.05)$ & (3.34) & $(-1.94)$ \\
\hline \multirow{2}{*}{$\begin{array}{l}\text { LEGALCT } \\
(x 100)\end{array}$} & $0.004 * * *$ & $0.019 * * *$ & 0.000 & -0.002 & $0.004 * * *$ & 0.004 & -0.001 & $0.006 * * *$ \\
\hline & $(4.56)$ & $(3.64)$ & (0.19) & $(-0.72)$ & $(4.34)$ & (1.61) & $(-0.42)$ & $(4.33)$ \\
\hline \multirow[t]{2}{*}{ REG } & $-0.077 * * *$ & - & - & - & $-0.075 * * *$ & $-0.089 * * *$ & $-0.072 * * *$ & $-0.038 * *$ \\
\hline & $(-11.86)$ & - & - & - & $(-10.99)$ & $(-4.81)$ & $(-4.48)$ & $(-2.66)$ \\
\hline \multirow[t]{2}{*}{$R E L(x 100)$} & $0.077 * * *$ & $0.003 * * *$ & $0.097 * * *$ & 0.014 & $0.068 * * *$ & $0.059 * * *$ & $0.045^{* * *}$ & $0.055^{* * *}$ \\
\hline & $(-11.86)$ & $(0.12)$ & (6.58) & $(1.16)$ & $(11.27)$ & (3.81) & $(4.43)$ & $(4.38)$ \\
\hline \multirow[t]{2}{*}{ RIT } & $-0.007 * * *$ & $-0.008^{* * *}$ & $-0.007 * * *$ & $-0.032 * * *$ & $-0.007^{* * *}$ & $-0.007 * * *$ & $-0.032 * * *$ & $-0.005^{* * *}$ \\
\hline & $(-7.68)$ & $(-3.39)$ & $(-3.38)$ & $(-8.85)$ & $(-6.70)$ & $(-3.94)$ & $(-7.22)$ & $(-3.60)$ \\
\hline \multirow[t]{2}{*}{ LANG } & $0.065 * * *$ & $-0.064 * *$ & $0.078 * * *$ & 0.011 & $0.061 * * *$ & $0.094^{* *}$ & 0.000 & $0.103 * * *$ \\
\hline & $(9.78)$ & $(2.00)$ & $(5.61)$ & $(0.50)$ & $(8.70)$ & $(4.93)$ & $(-0.01)$ & $(7.84)$ \\
\hline Adjusted $R^{2}$ & 0.1418 & 0.1713 & 0.1085 & 0.2332 & 0.1392 & 0.1813 & 0.2633 & 0.0491 \\
\hline F-Statistic & $186.97^{* * *}$ & $8.55^{* * *}$ & $23.13 * * *$ & $57.80 * * *$ & $161.55^{* * *}$ & $30.49 * * *$ & $88.70 * * *$ & $16.20 * * *$ \\
\hline
\end{tabular}

Note: The table presents the OLS results of the model. *, ** and ${ }^{* * *}$ denote the levels of significance at $1 \%, 5 \%$ and $10 \%$, respectively. 
Table 10: Culture blocs

\begin{tabular}{lr}
\hline & Full Sample \\
\hline KS*AngloSaxon & $-0.460^{* *}$ \\
& $(-2.27)$ \\
\hline KS*AngloSaxonW & $-0.038^{* *}$ \\
& $(-4.24)$ \\
\hline KS*Latin & $-0.369^{* * *}$ \\
& $(-3.71)$ \\
\hline KS*LatinW & -0.001 \\
& $(-0.07)$ \\
\hline KS*Chinese & -0.108 \\
& $(-1.11)$ \\
\hline KS*ChineseW & -0.001 \\
& $(-0.17)$
\end{tabular}

Note: The table presents the quantile regression results of the model on culture blocs. AngloSaxon refers to culture bloc consisting of market pairs from the UK, Australia, Canada and New Zealand; AngloSaxonW consists of AngloSaxon and non-AngloSaxon market pairs; Latin consists of Brazil, Mexico, and Argentina; LatinW represents Latin and non-Latin market pairs; Chinese consists of China, Hong Kong, and Singapore; ChineseW represents Chinese and non-Chinese market pairs. *,** and *** denote the levels of significance at $1 \%$, $5 \%$ and $10 \%$, respectively. $t$-statistics are reported in brackets. 


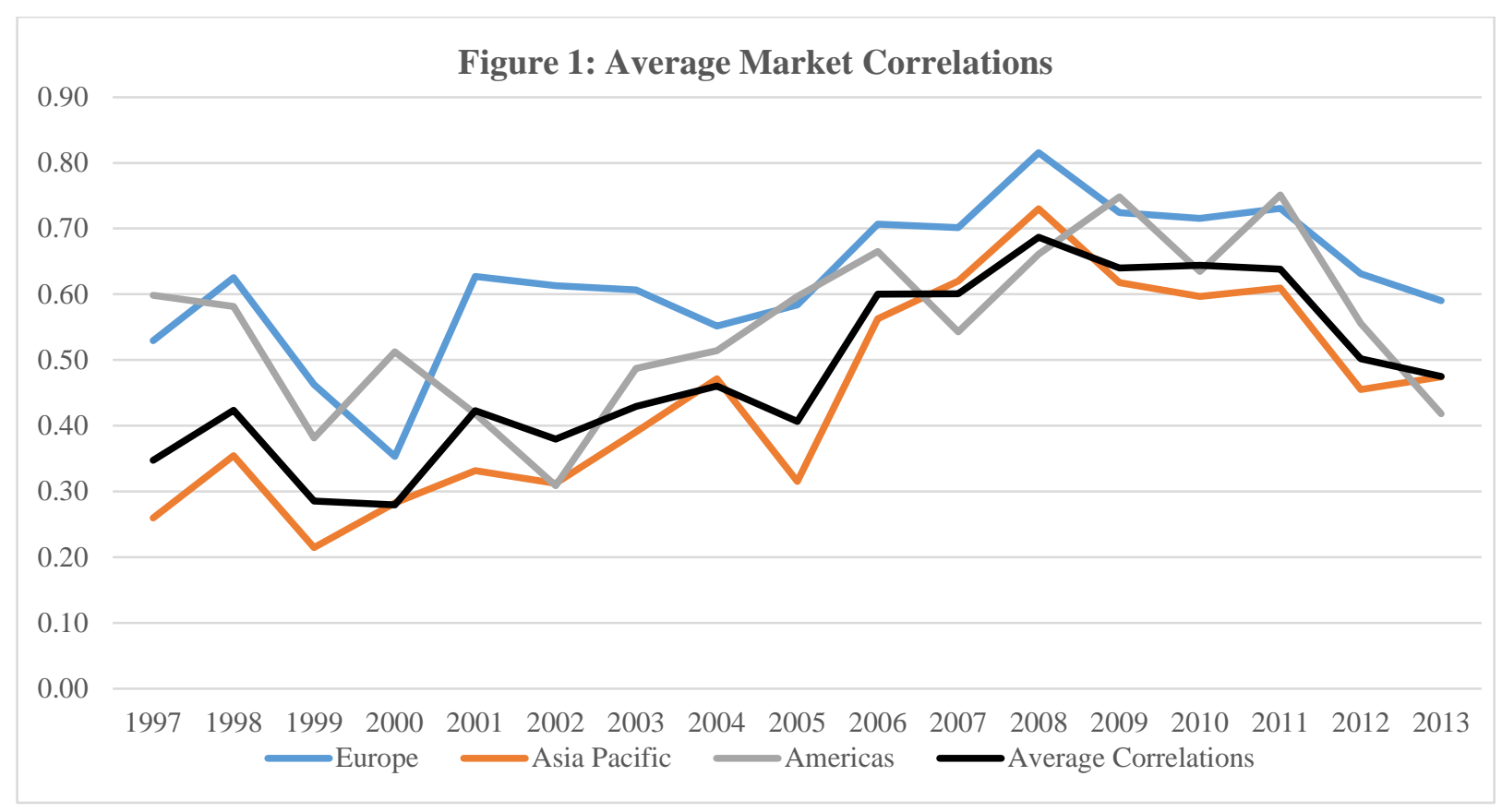

Source: MSCI Country Market Index, Thomson Reuters DataStream

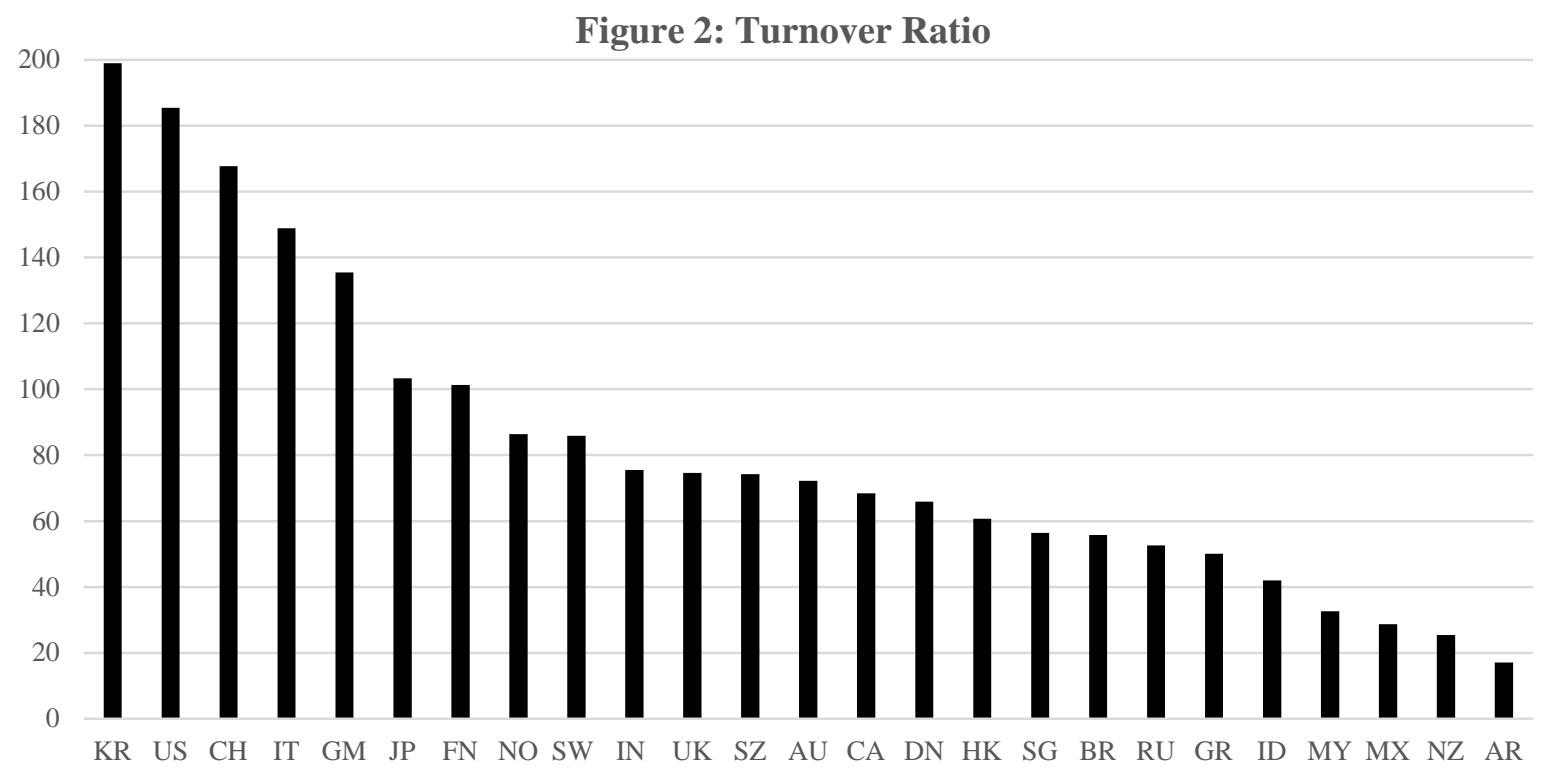

Source: World Development Indicators, World Bank (2012)

Note: Turnover ratio is calculated as the total value of shares traded during the period divided by the average market capitalization for the period. 


\section{Appendix A - Quantile distributions}

\section{$\underline{\text { Americas }}$}

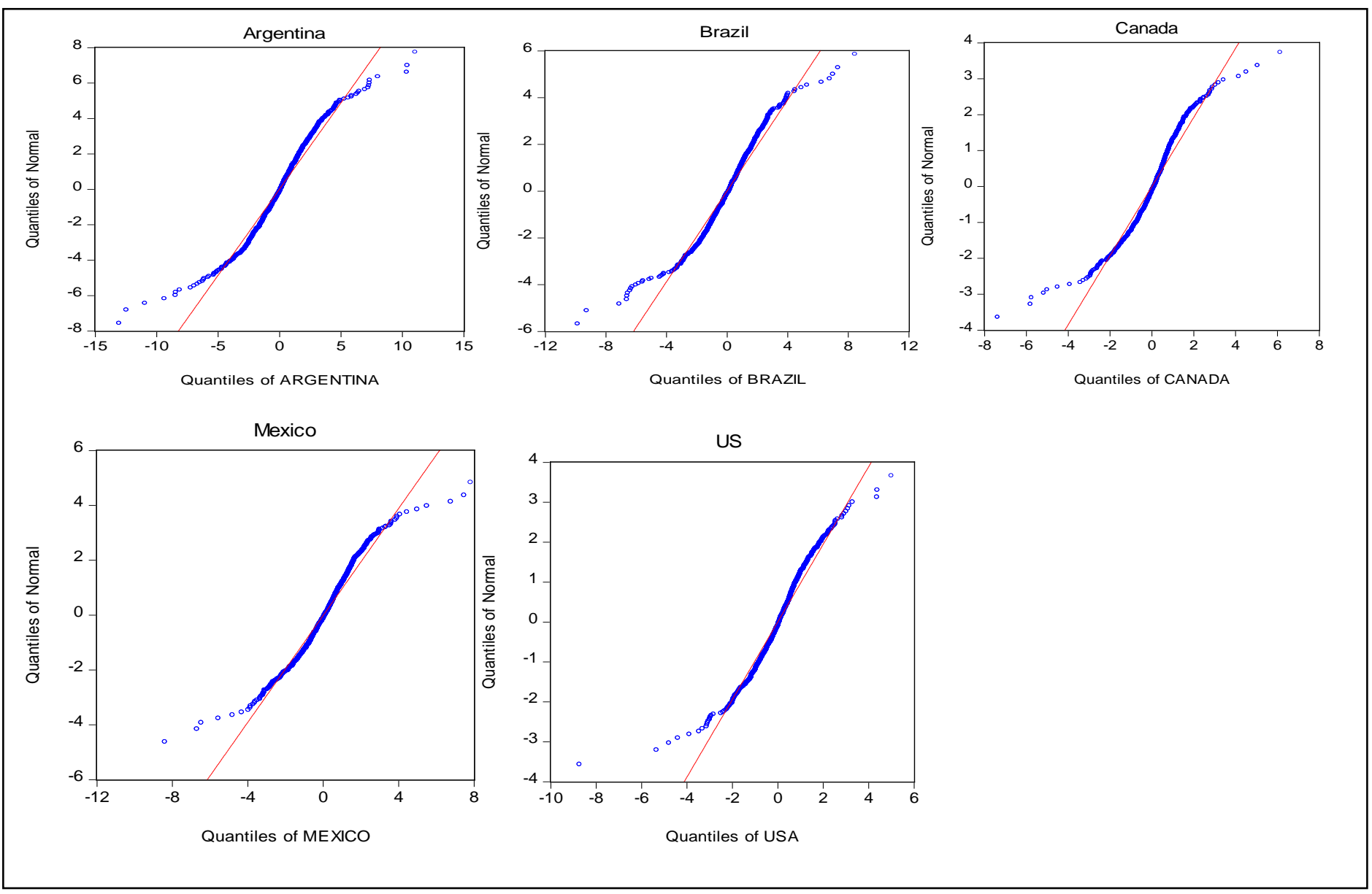


Page 37 of 43 


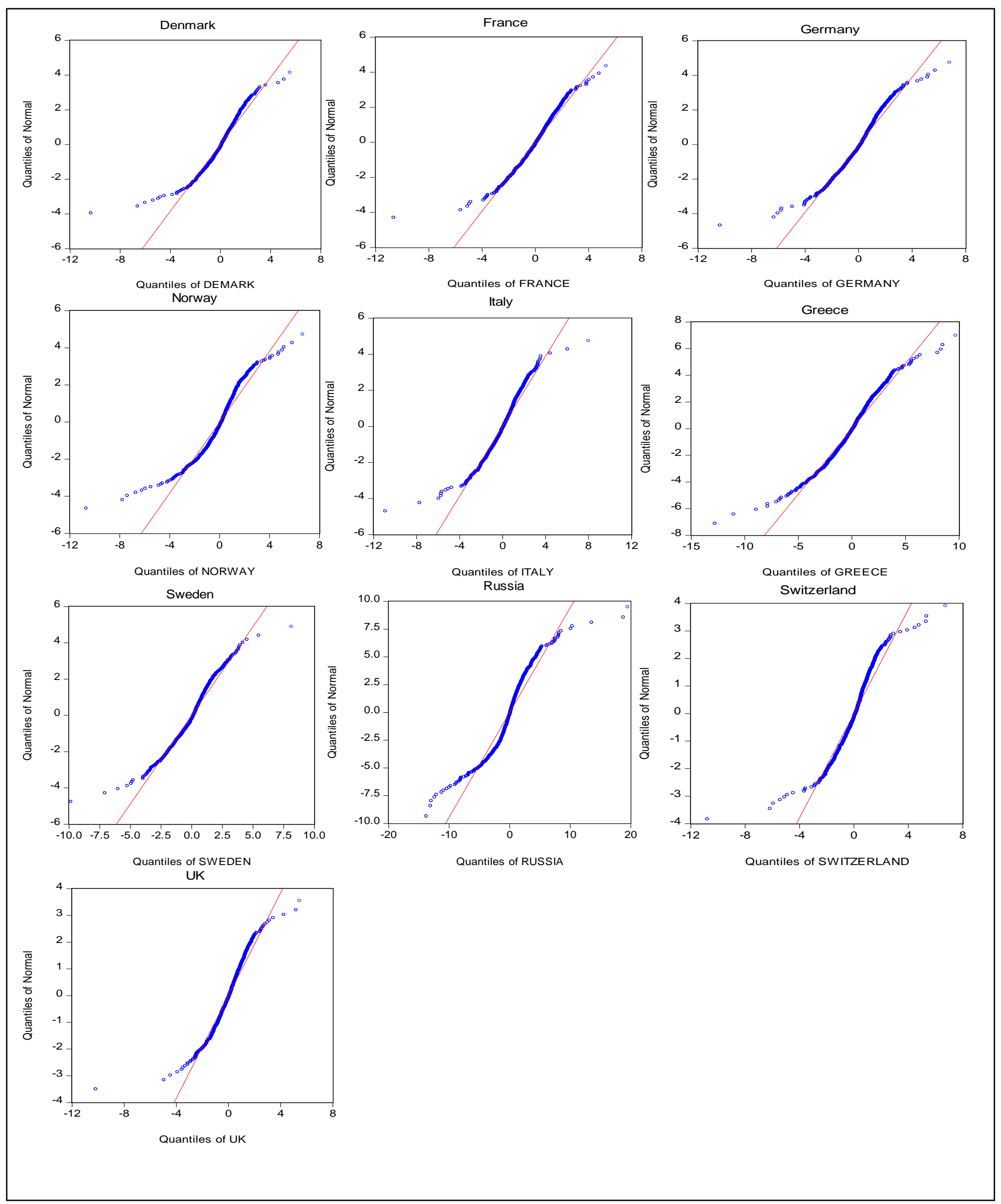


$\underline{\text { Asia-Pacific }}$

Page 39 of 43 


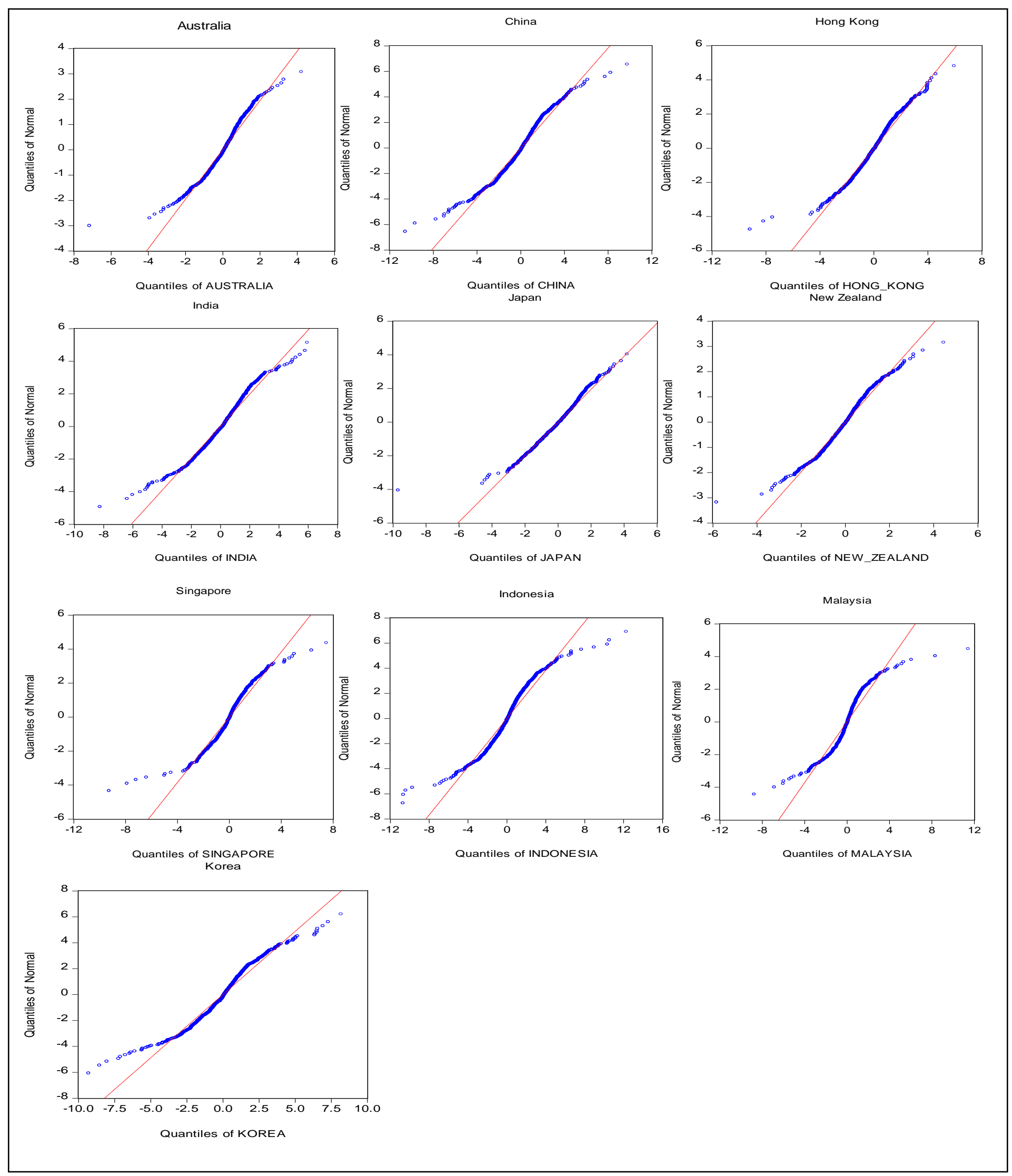

Page $\mathbf{4 0}$ of $\mathbf{4 3}$ 
Americas (log-difference)

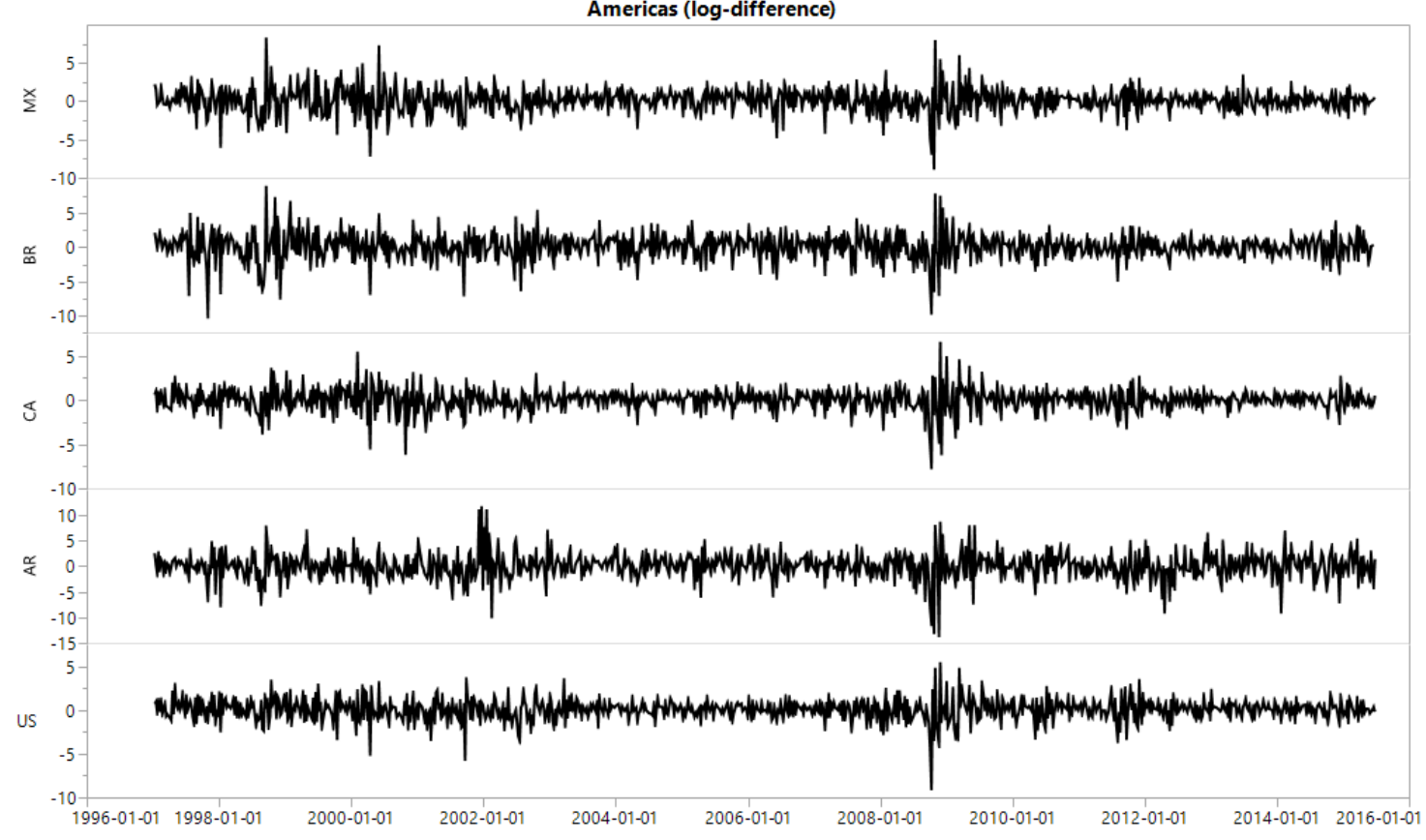

Asia-Pacific (log difference)

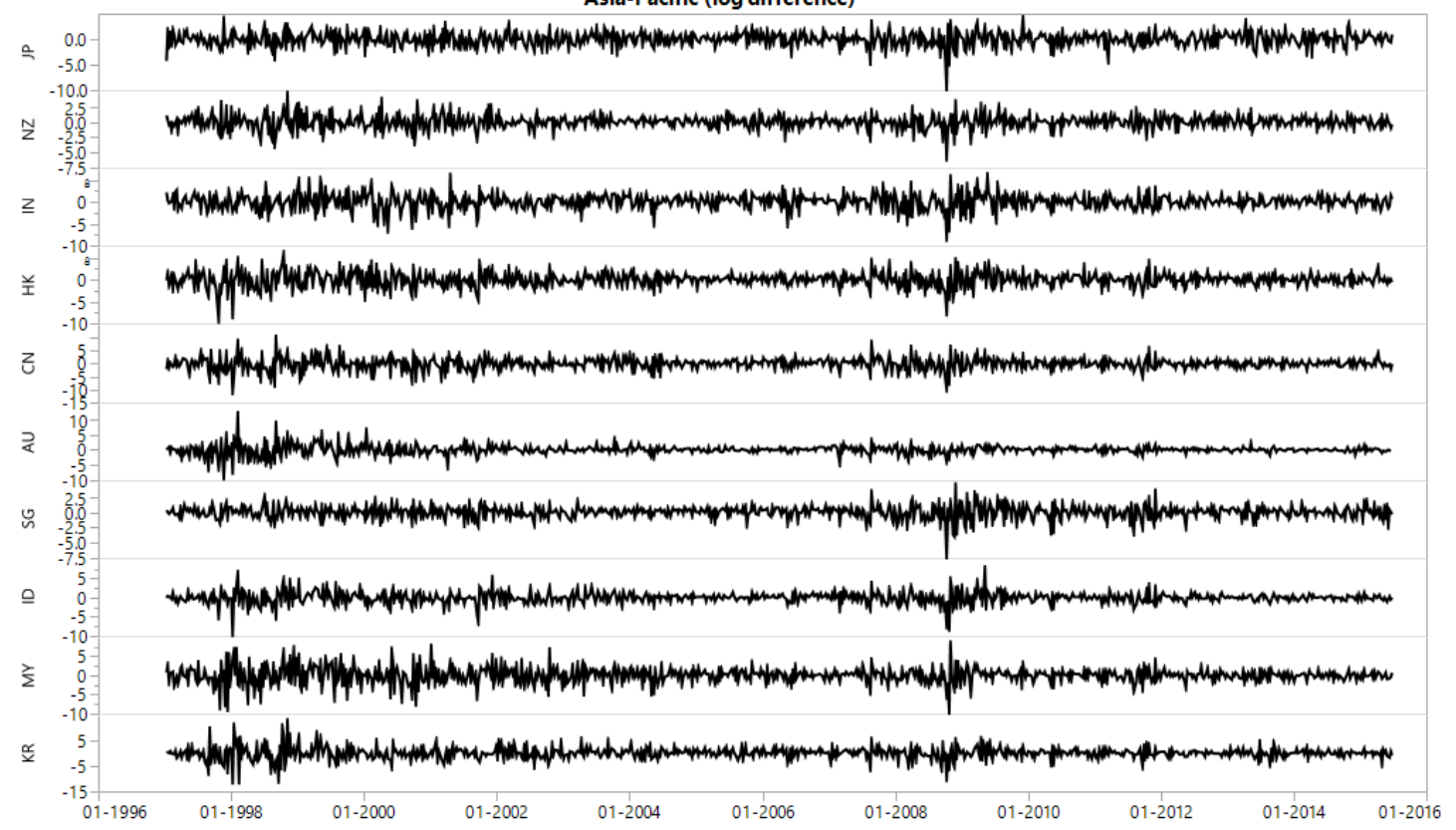


Europe (log-difference)

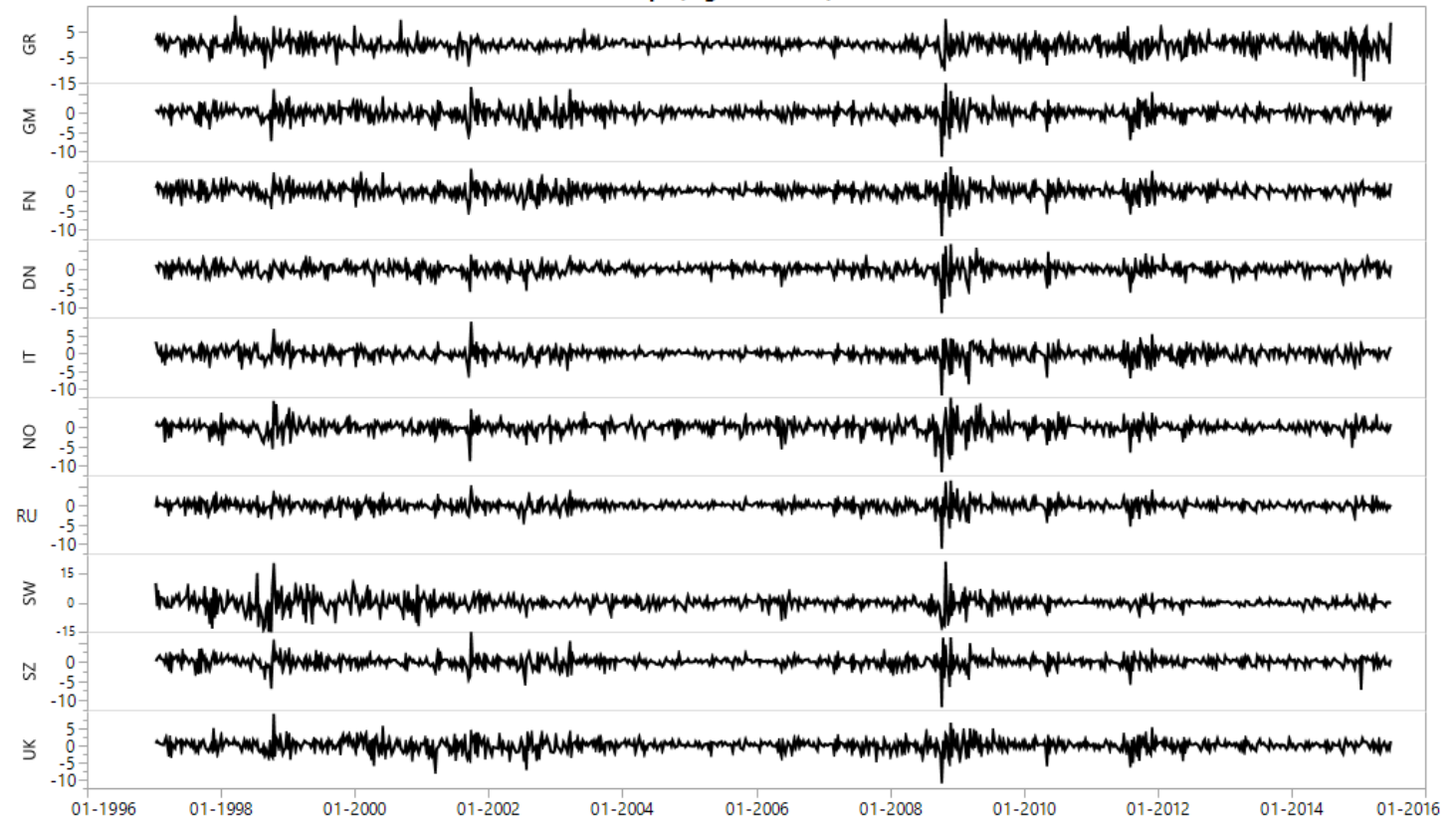




\section{Appendix C - Quantile Process Estimates}

DIS

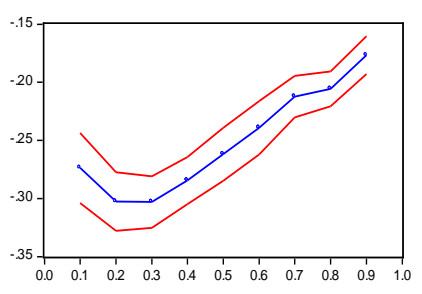

Quant

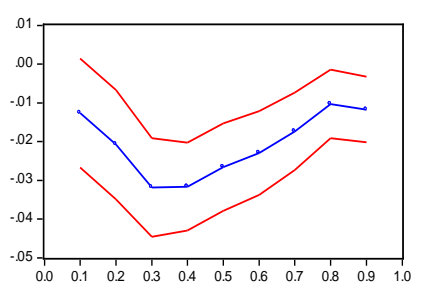

RIT

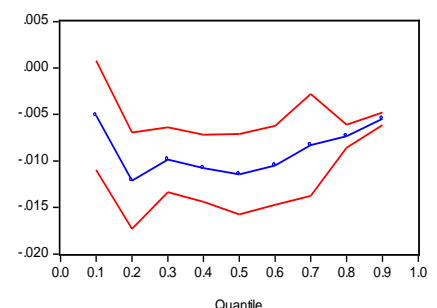

GDP

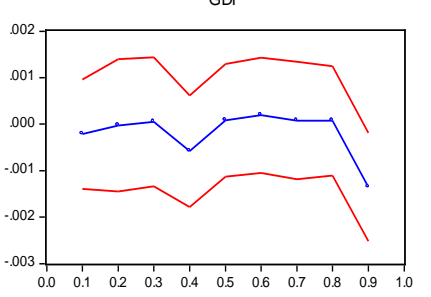

Quantle

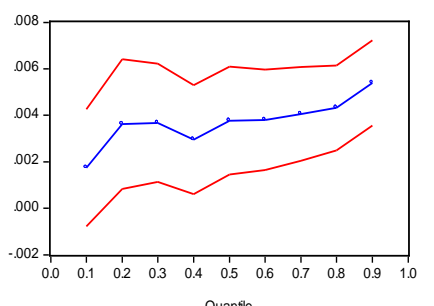

C

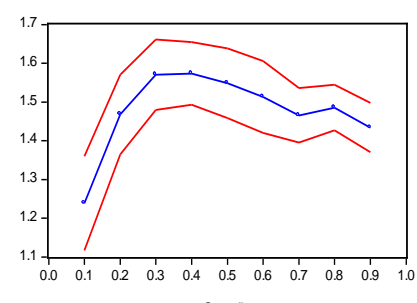

KS

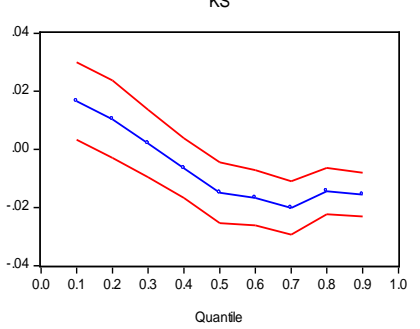

REG

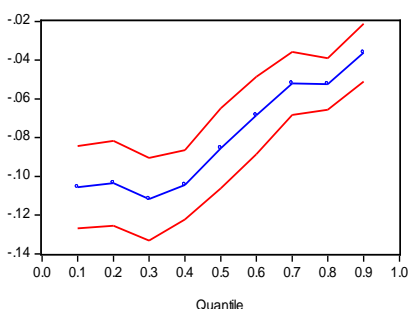

Quantile

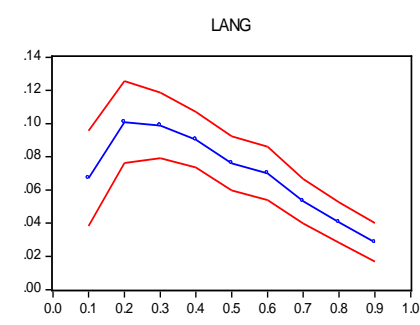

Quantile

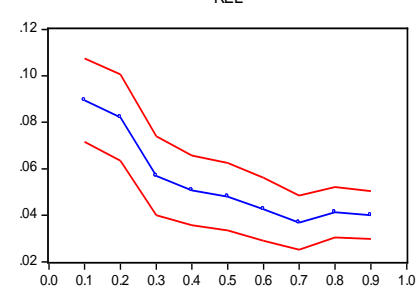

Quantle

Note: $K S$ is significant at q10, q15, q25, q50, q55, q60, q65, q70, q75, q80, q85, q90, q95. REL is significant at all quantiles. $L A N G$ is significant at all quantiles

$D I S$ and $R E G$ are significant at all quantiles. RIT is significant at all quantiles except q05. GDP is significant at quantiles q85, q90 and q95. $L E G$ is significant at all quantiles except q05 and q10. LEGALCT and $L E G$ are significant at qq15, q20, q25, q30, q35, q40, q45, q50, q55, q60, q65, q70, q75, q80, q85, q90, q95. 